\title{
Jolanta Skutnik
}

Uniwersytet Śląski

e-mail: jolanta.skutnik@us.edu.pl

\section{„Co to jest muzeum” - wyobrażenia dzieci w wieku pomiędzy piątym a siódmym rokiem życia na temat instytucji muzealnej}

\author{
Abstract \\ „What is a Museum” - Children's Notion (between the 5 and 7) \\ about the Museum's Institution
}

This document presents the results of research on the perception of the museum by younger children (aged 5 to 7 years). The research was carried out in a group of 250 children attending kindergartens in the Silesian Voivodship. The results of the research served to get to know how children perceive the museum as an institution, its tasks and functions. This knowledge should be preceded by all educational activities of museums.

The qualitative strategy with the methodology associated with the interpretive paradigm was chosen for the implementation of the research. Assuming that children are not able to accurately answer questions related to defining concepts and phenomena, research should be based on such methods of expression that would reproduce the image of the analyzed phenomenon in the most readable manner possible. One of the most frequently used forms of observation of children's ideas about the world are children's drawings. Hence drawing as a research technique, in the case of children's questions about phenomena and definitions, it proved to be the most appropriate research tool, allowing to reproduce these fragments of knowledge, experiences, insights and opinions of children who can't be verbalized. This did not mean giving up verbal statements. From the research experience it is clear that these two methods of data acquisition, in the case of younger children, should occur together, eliminating any possible understatements resulting from the use of any of the methods separately. Their simultaneous use eliminated possible false ways of reading data. That is why, apart from the drawing (as projection techniques), the method of focused group interviews was used. Interviews were conducted with children in groups (8 groups in total), the number of which ranged from 5 to 8 people. 
As a result of the research, a rich research material was obtained, including 250 drawings and over a two-hour collection of verbal statements. Detailed analysis with conclusions is the content of this article.

Keywords: children, visitors, museum, perception, definition, drawings, interviews

Słowa kluczowe: dzieci, publiczność, muzeum, percepcja, definicja, rysunki, wywiady

\section{Wstẹp}

Człowiek wchodzący w nowe środowisko zwykle dysponuje jakimś apriorycznym wyobrażeniem na jego temat. Nierzadko to wyobrażenie decyduje nie tylko o sposobach nawiązania z owym środowiskiem kontaktu, ale także wpływa na ewentualne podtrzymywanie lub porzucenie tego ostatniego. Wyobrażenie takie potencjalnie może stać także u podstaw kształtowania się form zainteresowania kulturą reprezentowaną w jej instytucjonalnych formach. Nie powinna zatem dziwić potrzeba zadawania pytań o to, jaki obraz instytucji kultury noszą potencjalni uczestnicy, odbiorcy tej oferty. Pominąwszy merkantylne uwarunkowania związane z rozwijaniem publiczności instytucji jako siły wspierającej (a nierzadko utrzymującej) ją finansowo, warto zadawać takie pytanie ze względu na zakładane funkcje społeczne działalności instytucji, których misyjne zadania wpisują się różne formy i sposoby upowszechniania kultury. Te, w zależności od dziedziny, korelują z różnymi sferami ludzkiej działalności, wśród których zaczynają dominować działania edukacyjne (nierzadko wywołane rosnącą w skali światowej koncepcją całożyciowego uczenia lifelong learning). Ilustracją tego typu doświadczeń może być zmiana, jaka dokonała się w działalności placówek muzealnych. Od lat sześćdziesiątych ubiegłego wieku, zarówno na świecie, w Europie, jak i w Polsce (choć tu znacznie później) rozwijają się działania skoncentrowane na publiczności muzealnej. Odejściu od biernej formy odbioru treści w kierunku uczynnienia publiczności współtworzącej szeroko rozumiane środowisko działalności muzealnej towarzyszą rozmaite próby jej edukowania „do”, „W” i „poprzez” muzeum. Działalność ta, jakkolwiek luźno powiązana (lub w ogóle niepowiązana) z procesem formalnej edukacji, w ramach której metodyka kształcenia wyrasta z uwarunkowań rozwojowych, powinna przekraczać intuicyjne podejście do pracy z publicznością (nierzadko jeszcze obserwowane w tego typu placówkach). Wszak podmiotem tych działań, jeśli odpowiedzialnie myślimy o upowszechnianiu kultury, jest człowiek. Usytuowanie człowieka w centrum zaangażowań współczesnego muzeum zmusiło je, a w zasadzie służby odpowiedzialne za kreowanie kontaktów z publicznością, do podejmowania rozmaitych prób jej poznania. Wiedza wywiedziona $\mathrm{z}$ analiz pomaga dziś tworzyć programy, które nie tylko skupiają się na merytorycznej wiedzy wynikającej ze specyfiki placówki muzealnej, ale opierają się na wynikach bezpośrednich badań publiczności muzealnej. Te pozwalają określić 
zakres potrzeb publiczności wobec muzeum, ustalić optymalne warunki zwiedzania, weryfikować narzędzia i środki komunikacji umożliwiające optymalizację programów upowszechnieniowych. Dzięki takim analizom programy instytucji, w tym muzeów, coraz mocniej zbliżają się do klasycznego ujęcia edukacji jako formy kształcenia i wychowania w jego osobotwórczym wymiarze.

\section{Rozwój visitor studies - ramowy przeg̣ląd badań nad publicznością muzealną}

Problematyka visitor studies od wielu lat stanowi jedną z głównych osi dyskursu naukowego wokół muzeum, jego nowych funkcji i definicji. Pierwsze poważne badania publiczności muzealnej przypadają na drugą połowę XIX wieku. Już w 1884 roku H.H. Higgins przedstawił efekty pierwszych obserwacji publiczności, w ramach której wyłonił grupy zwiedzających różniące się zainteresowaniami i różnym stylem zwiedzania [Higgins 1884]. W roku 1916 muzeolog B.I. Gilman w periodyku „Scientifc Monthly" opublikował wyniki systematycznych badań nad zmęczeniem muzealnym [Soeven 1993]. W latach dwudziestych XIX wieku O. Neurath na wystawie poświęconej zmianom społecznym zorganizowanej w Muzeum Ekonomiczno-Społecznym w Wiedniu dokonał oceny publiczności, na podstawie której opracował metodę wystawiennictwa znaną jako Isotype (International System of Typographic Picture Education) [Soeven 1993]. Każdy z prekursorów badań publiczności stawiał sobie za cel jej poznanie. Wyodrębnienie potrzeb i oczekiwań zwiedzających w stosunku do konkretnej tematyki ekspozycji miało optymalizować strategię komunikacyjną w taki sposób, aby umożliwić odbiorcy dogłębną penetrację treści stanowiących potencjalnie przedmiot zainteresowań zwiedzających. W następnych latach kolejne grupy badawcze doskonaliły i pogłębiały pierwsze analizy: od końca 1928 do początku 1931 roku E.S. Robinson i A. Melton pod auspicjami Amerykańskiego Stowarzyszenia Muzeów i Fundacji Carnegie, przeprowadzili serię badań, dzięki którym ustalili, jak przebiega przeciętny pasaż muzealny, natomiast $\mathrm{H}$. Shettl, używając makiet do obserwacji reakcji publiczności na konkretne przedmioty z kolekcji, przeanalizował optymalne warunki ekspozycji muzealiów [Soeven 1993].

W Polsce w latach sześćdziesiątych ubiegłego wieku w ośrodkach warszawskim, krakowskim i przemyskim zaczęto prowadzić podobne badania publiczności. Pierwsze sondaże ankietowe realizowano w 1951 roku w Muzeum Sztuki w Łodzi. W roku 1959 Halina Winiecka przeprowadziła w Muzeum Pomorza Zachodniego w Szczecinie studia nad publicznością wystawy rzeźb Henry’ego Moore’a. W tym czasie badania nad publicznością muzealną prowadzone były także w Muzeum Śląskim we Wrocławiu. W 1964 roku przy Muzeum Narodowym w Krakowie powstała Pracownia Badań Socjologicznych, którą od roku 1969 kierował Tadeusz Gołaszewski, pedagog i socjolog badający publiczność tej placówki muzealnej. Te i inne wyniki badań prezentowane były między innymi na międzynarodowym Seminarium 
ICOM na temat „Muzeum a nowa publiczność”, które odbyło się we wrześniu 1968 roku w Krakowie. Badaczy tego okresu, reprezentujących głównie środowisko socjologiczne, zajmowały zwłaszcza kwestie relacji widzów na zmiany godzin otwarcia muzeum, problemy ustalenia dolnej granicy wieku osób odwiedzających muzea, skuteczność działania celowych wystaw oświatowych i innych form aktywizacji widzów [Ziembiński 1990]. Co warto podkreślić, większość z prowadzonych w tym okresie w Polsce i na świecie badań reprezentowała ujęcie ilościowe, statystyczne, nierzadko obserwowane zresztą też współcześnie. To dzięki takim analizom można określić profil przeciętnego przedstawiciela publiczności muzealnej, który mieści się w opisie białego człowieka, reprezentanta klasy średniej, dobrze wykształconego i uposażonego, pracującego, przemieszczającego się z użyciem własnego środka lokomocji, pozostającego w związku małżeńskim oraz posiadającego dzieci [Bourdieu, Darbel 1991, Doering, Bickford, Pekarik 1997].

Dziś, w kontekście nowych wymagań nowego muzeum i jego zmieniającej się publiczności, efekty badań ilościowych nie wystarczają do planowania zadań instytucji muzealnych. Nie jest to szczególnie odkrywcze założenie. Już w okresie powojennym, wartość analityczną i użyteczność tych analiz poddawano w Polsce krytyce, pisząc, że co prawda

nie ma w Polsce średniego co do wielkości muzeum, w którym nie prowadzono by nigdy lustracji publiczności, nie zbierano, w mniej lub bardziej sformalizowanej postaci, wypowiedzi widzów. (...) Niewątpliwie na powszechność tych starań znaczny wpływ wywarło zarządzenie Ministra Kultury i Sztuki z roku 1952, które zalecało prowadzenie badań nad celowością i użytecznością stosowanych form pracy oświatowej, w którym wymieniano, jako pożądane narzędzia poznania, lustracje ankietowe i organizowanie $\mathrm{z}$ widzami publicznych dyskusji nad czytelnością wystaw. Nie wszystkie [jednak - J.S.] spośród lustracji ankietowych nazwać możemy badaniami naukowymi. Pamiętajmy, że większość z nich prowadził personel muzealny, nieprzygotowany merytorycznie do badań socjologicznych. (...) Ponadto w szeregu z nich nie sprecyzowano jasno celu badań, ich autorzy ograniczali się jedynie do ogólnie interesujących kwestii, takich jak opinie widzów o ekspozycji, czy ich upodobania odbiorcze” [Mikułowski-Pomorski 1973: 74].

Pomimo rozpoczętych badań i wskazanych założeń już w kolejnych latach aktywność badawcza skierowana na tę specyficzną populację uczestników życia kulturalnego ustała. Jej ożywienie jednak staje się coraz bardzie potrzebne.

Według danych Narodowego Instytutu Muzealnictwa i Ochrony Zbiorów w 2013 roku polskie muzea odwiedziło prawie 21 milionów osób [Muzea 2016]. W lekcjach muzealnych, które stanowią zaledwie jedną z wielu propozycji muzealnych uczestniczyło prawie 1,7 mln odbiorców. Z roku na rok te liczby zwiększają się. Z analiz sporządzanych przez Główny Urząd Statystyczny wynika, że w 2014 roku polskie muzea odwiedziło $30 \mathrm{mln} 609$ tys. zwiedzających, w 2016 roku 36,1 mln osób, 
a w 2017 roku 37,5 mln osób ${ }^{1}$. Wzrost frekwencyjny jest zatem znaczący. To rosnące zainteresowanie publiczności ofertą polskich muzeów nie przekłada się jednak na stały udział zróżnicowanych grup społecznych i osób indywidualnych w ofercie, która kierowana jest ciągle do statystycznego odbiorcy/konsumenta. Wypływające jedynie ze statystycznych ujęć myślenie o kulturze nie sprzyja percepcji oferty instytucji kultury, w tym muzeów, której to perepcji efektem miałby stać się pogłębiony model uczestnictwa w kulturze - pogłębiony, czyli taki, który nie tylko opiera się na podejściu konsumenckim i ludycznym, ale także wpływa znacząco na rozwój postaw i kształtowanie świata wartości.

Włączenie do debaty o społecznej misji muzeów zagadnień związanych z kształtowaniem świata wartości, odpowiedzialności za ich ochronę i przetrwanie nieuchronnie wiąże ich działalność z teorią i praktyką edukacyjną. „Edukacyjny zwrot muzealny”, przypadający w Europie w największym stopniu na lata osiemdziesiąte ubiegłego wieku, staje się codziennością polskich placówek muzealnych. Muzea starają się zająć znaczące miejsce wśród podmiotów kształtujących świadomość społeczeństwa i jego jednostek zarówno w odniesieniu do historii, jak i współczesności. W tym celu przechodzą od praktyki „świątynnej” do aktywności edukacyjnej opartej na aktywnym uczestnictwie w obcowaniu z muzeum, muzealium i znaczeniami przez nie reprezentowanymi. Tym samym zmieniają się strategie pracy z publicznością: od modelu pasywno-komplementacyjnego, opartego na przyswajaniu wiedzy, do modelu afektywno-refleksyjnego, którego wartością jest samodzielne dochodzenie do wiedzy, jej intelektualna obróbka i wykorzystanie. Jednak bez względu na to, jaką optykę pracy edukacyjnej przyjmuje się w placówkach muzealnych, niezmiennym elementem pozostaje podmiot tej aktywności - publiczność.

Kategoria publiczności muzealnej nie jest wartością stałą. Zmienność charakteryzująca tę populację wymaga namysłu, szczególnie w tej sferze, która dotyka procesu edukacji rozumianego nie tylko jako forma przekazu wiedzy, ale bardziej jako sposób kształtowania postaw, wzbudzania zainteresowań, pogłębiania kultury indywidualnej. Wynika stąd potrzeba poznawania publiczności, szczególnie w kwestiach dotyczących jej motywacji do uczestnictwa w ofercie muzealnej. Jednym z najważniejszych elementów kształtowania się motywacji jest stosunek do instytucji i jej oferty. Jego zarysy w postaci wyobrażeń na temat instytucji powstają już we wczesnym dzieciństwie. Wówczas kształtują się pierwsze sposoby postrzegania i myślenia o instytucji, które właściwie rozwijane, pielęgnowane lub modyfikowane mogą w przyszłości owocować zainteresowaniem ofertą instytucji a nawet przeradzać się w formy pełniejszego partycypowania w ich działaniach.

${ }^{1}$ Por. https://stat.gov.pl/obszary-tematyczne/kultura-turystyka-sport/kultura/dzialalnosc-muzeow 


\section{0gólne uwarunkowania ksztaltowania się wyobrażeń dziecięcych w wieku przedszkolnym}

Dzieci, których liczbę w grupie zwiedzających muzea szacuje się na 15\% ogólnej populacji [Statystyka 2017] ${ }^{2}$, przychodzą do muzeum z jakimś jego wyobrażeniem. Nawet najmłodsze z nich mają bowiem ukształtowane wyobrażenia o świecie, obejmujące również muzeum. Na obraz świata w tej jego części istotny wpływ wywierają ich indywidualne doświadczenia zdobywane na przykład podczas kontaktów z ofertą instytucji kultury ale także ich medialne obrazy świadomie lub nieświadomie przyswajane przez dzieci poprzez media lub w trakcie zabawy z rówieśnikami. Wpływ ten wzbogacają nieustannie wcześniejsze nastawienia dorosłych rodziców, opiekunów, członków rodziny lub rówieśników wobec muzeum (bez dociekania poziomu ich świadomości) [Skutnik 2018]. Od charakteru tych zbiorczych wyobrażeń zależą nastawienia dzieci do tej instytucji i jej oferty, a także późniejsze nią zainteresowania, stosunek do wartości przekazu, a w końcu liczba i rozległość kontaktów kulturalnych już na kolejnych etapach rozwoju. Wyobrażenia na temat muzeum interesujące są jednak nie tylko z punktu widzenia jednostkowych procesów rozwojowych, ale wiążą się z określaniem celowości i jakości działań podejmowanych w stosunku do uczestników oferty muzealnej. Pierwotny obraz instytucji wypływa z dziecięcych o niej wyobrażeń, powinien stać się podstawą do konstruowania pierwszych kontaktów, które miałyby potencjalnie rozwinąć się w stałe zainteresowanie ofertą muzealną i jej współtworzeniem.

Pytając dzieci młodsze o to, czym jest muzeum, uwagę badawczą należy skoncentrować zatem na wyobrażeniach, w ramach których mieszczą się ich wiedza, doświadczenia i sądy. I chociaż dzieci różnią się od siebie osobowościowo, to pewne cechy fizyczne i psychiczne można im przypisywać ogólnie jako reprezentantom określonej grupy rozwojowej (pomiędzy trzecim a siódmym rokiem życia) [Przetacznikowa, Makiełło-Jarża 1974]. Ten sprzyjający obserwacjom okres rozwojowy, w którym zachodzą poważne zmiany natury fizjologicznej i psychologicznej, stanowi ważną podbudowę do kształtowania się dojrzałych postaw także uczestników kultury.

Na etapie rozwoju ontogenetycznego, który w literaturze przedmiotu określany jest jako wiek przedszkolny, dziecko intensywnie poszerza swoją orientację w świecie zewnętrznym. U podstaw tej zmiany leżą specjalizujące się zmysły pobudzające intensywny rozwój procesów poznawczych, w tym spostrzeżeń, pamięci i myślenia.

2 Por. Statystyka muzeów. Muzea w 2016 roku, Warszawa: Narodowy Instytut Muzealnictwa i Ochrony Zbiorów, 2017. Wskazana wartość dotyczy ogółem grup dziecięcych, w której to kategorii nie wyróżniono podgrup ze względu na wiek. Nieco więcej na temat udziału dzieci młodszych w ofercie muzealnej mówią wyniki analiz dotyczących stanu edukacji muzealnej w Polsce. Wskaźnik udziału dzieci przedszkolnych w zajęciach o charakterze edukacyjnym w muzeach wynosił $44 \%$. Podobna wartość odnosiła się udziału rodzin z dziećmi w programach muzealnych - 40\% wszystkich grup. Por. Muzea $w$ Polsce... 
Efektem rozwojowym tego okresu jest pierwsza ważna postać dostosowania się do otaczającego środowiska, która nie oznacza jednak biernego konsumowania, ale wskazuje (co prawda wstępnie) możliwość działania w nim. Stopniowe doskonalenie się tych funkcji (np. w procesie regularnej edukacji, pozaformalnej aktywności indywidualnej, obserwacji postaw modelowych itd.) pozwala wraz ze wzrostem społecznym stać się czynnym członkiem grupy, w której człowiek żyje - również takim, który decyduje o kształcie, potrzebie działania i zadaniach instytucji kultury, w tym muzeów.

U podstaw kształtowania się procesów poznawczych dzieci młodszych sytuują się wrażenia i spostrzeżenia, których rozwój wzmagają liczne podniety płynące ze świata zewnętrznego. Spostrzeganie zatem staje się pełniejsze za sprawą coraz mocniej specjalizującej się działalności dziecięcej, której katalizatorami są bodźce zewnętrzne (obrazy, dźwięki, zapach, wrażenia dotykowe). Ta wrażliwość na rozmaite bodźce skłania dzieci do zainteresowania się poszczególnymi dziedzinami ludzkiej aktywności, np. twórczością artystyczną. Co ważniejsze z punktu prowadzonych badań, podniety te wyzwalają mocny potencjał spostrzeżeń, które początkowo co prawda mają charakter synkretyczny, jednak u znacznej części dzieci ujawniają cechy wrażliwych obserwatorów. Z natłoku wrażeń wiele dzieci potrafi wyłuskać szczegóły, na które dorosły zwykle nie zwraca uwagi, a które wzmacniają pozytywny lub negatywny obraz zjawiska poddanego oglądowi. Nieodmiennie, spostrzeżeniom tym sprzyjają tzw. silne bodźce, których udział w recepcji doświadczeń świata zewnętrznego jest niezwykle ważny (silny bodziec, bez względu na jego związek z obserwowanym doświadczeniem, może zmodyfikować, zmienić, a nawet zafałszować przekaz i w takiej postaci zapisać się w pamięci) [Przetacznikowa 1975]. Drugim elementem modelującym kształt spostrzeżeń jest ich ścisły związek z działaniem. Dziecko znacznie więcej dostrzega $\mathrm{w}$ trakcie operowania przedmiotem, działania $\mathrm{z}$ wykorzystaniem przedmiotów i w otoczeniu działających ludzi aniżeli w trakcie doświadczeń ograniczonych do jednej sfery sensorium, np. słuchu [Przetacznikowa 2000]. Trzecim warunkiem kształtowania się spostrzeżeń, związanym mocno z poprzednimi, są emocje. Dziecko zwraca baczniejszą uwagę na akcenty, które wywołują w nim silniejsze emocje lub je ilustrują (np. rysunki, reprodukcje, filmy), niż na te, które podawane są w „chłodny sposób”, bez manifestowania emocji [Przetacznikowa 1975]. Warunkiem „ocieplającym” lub „ochładzającym” te przekazy bywa obecność osób obcych lub znanych dziecku. Co ważniejsze, i na co wskazują doświadczenia psychologów, dziecko w ostatniej fazie rozwoju przypadającej na

${ }^{3}$ Rozróżnienie pojęć recepcji i percepcji, ze względu na różne definiowanie procesów, wymaga uściślenia. W teoriach psychologicznych recepcja sensoryczna jest wczesnym procesem biernej rejestracji informacji, odzwierciedleniem bodźców w receptorach. Percepcja (jako późniejsza od recepcji) jest aktywnym procesem polegającym na interpretacji danych zmysłowych z wykorzystaniem wskazówek kontekstualnych, nastawienia i wcześniej nabytej wiedzy [Nęcka, Orzechowski, Szymura 2006]. 
okres przedszkolny, zbliża się do fazy spostrzegania rzeczywistości na etapie stadium stosunków, a w wielu przypadkach tę fazę osiąga. Potrafi zatem dostrzegać i opisywać doświadczenia świata zewnętrznego poprzez sytuowanie tych doznań w perspektywie doświadczeń społecznych. Stąd otoczenie społeczne, w którym rozgrywają się doświadczenia dziecięce, jak i jego rozmaite ilustracje, powinny być związane z obecnością w nim osób rozpoznawanych przez dziecko jako pozytywne (bo zapewniające np. bezpieczeństwo) zaplecze dla jego aktywności.

Spostrzeżenia wzbogacają dziecięcą wyobraźnię i sprzyjają rozwojowi niezwykle ważnej funkcji symbolicznej, której przejawem, obok mowy i zabaw tematycznych, są obrazy umysłowe (tzw. image mentale), czyli wyobrażeniowe reprezentacje przedmiotów i zjawisk [Przetacznikowa 1975, Kielar 1987]. To z punktu widzenia rozwijanych analiz kluczowy element rozważań, za pomocą którego można określić sposób kształtowania się obrazu rzeczywistości, w tym wyobrażenie o muzeum.

Struktura psychologiczna tych wyobrażeń jest dwojaka. Mogą one występować jako swoiste następstwo spostrzeżeń wynikających z obserwacji świata realnego wówczas przyjmują charakter obrazów reprodukcyjnych. W drugim znaczeniu są obrazami antycypacyjnymi, których podstawę stanowią wyobrażenia na temat zjawisk, zdarzeń, rzeczy i ludzi. Z doświadczeń Piagetowskich wynika wyraźnie, że obrazy reprodukcyjne wyprzedzają genetycznie czynności umysłowe, które towarzyszą antycypacji wyobrażeniowej. Oznacza to, że u podstaw wyobrażeń dzieci na temat świata znajdują się rzeczywiste doświadczenia, których fragmenty uczestniczą w konstruowaniu obrazu umysłowego zjawiska [Piaget, Inhelder 1967]. W procesie tym ważną rolę odgrywa pamięć.

Maria Przetacznikowa zaznacza:

Dziecko w wieku przedszkolnym gromadzi ogromne zasoby doświadczeń, być może większe niż te, które człowiek zdobywa w ciągu całego dalszego życia. Dziecko gromadzi doświadczenia w różnych dziedzinach i płaszczyznach - ruchowej, poznawczej, emocjonalnej i społecznej; $\mathrm{w}$ kontaktach $\mathrm{z}$ dorosłymi i rówieśnikami; wykonując czynności na przedmiotach oraz $\mathrm{w}$ toku czynności umysłowych i werbalnych [Przetacznikowa 1975: 450].

Doświadczenia te budują zasoby pamięci bezpośredniej i trwałej. Dzięki pamięci bezpośredniej - świeżej, dzieci doskonale radzą sobie z realizacją krótkich i intensywnych zadań, na przykład w zabawie. Wiadomo jednak, że w kształtowaniu się dojrzałości społecznej ludzi ważniejszą funkcję odgrywa pamięć trwała jako rezerwuar doświadczeń, wiedzy, które wykorzystywane są w następnych okresach rozwojowych. O ile jednak te przekonania są oczywiste i powszechnie znane, o tyle warto przyjrzeć się innej cesze dziecięcej pamięci, jaką jest zdolność do reminiscencji. To ważne zjawisko mnemiczne u dzieci w wieku przedszkolnym, które wskazuje na zdolność 
polepszania się zapamiętywania „po przerwie” lub „po pewnym czasie” bez dalszego „świadomego" uczenia się materiału. (...) Młodsze dzieci spostrzegają materiał bardziej bezpośrednio i w sposób bardziej emocjonalny niż dzieci starsze i dorośli, dlatego pełniejsza i sensowna jest u nich dopiero reprodukcja odroczona, natomiast pierwsze odtwarzanie jest często fragmentaryczne i subiektywne, pozbawione logicznej ciągłości. (...) Fakty i wiadomości utrwalone w pamięci w okresie dzieciństwa utrzymują się dłużej [Przetacznikowa 1975: 453].

Oznacza to, że nabytki pamięci dziecięcej są znacznie trwalsze niż zapamiętane przez dorosłych treści i doświadczenia (pamięć dorosłych charakteryzuje się rozległością i uporządkowaniem, które są niedostępne dla dziecięcej pamięci). Z tych rozważań płynie jednak istotny wniosek, notabene spopularyzowany dzięki sentencji: „Czym skorupka za młodu nasiąknie...”.

Rozwój mechanizmów wyobrażeniowych, tak charakterystyczny dla wieku przedszkolnego, stanowi podstawę kształtowania się myślenia i działania dziecka sprzyja zatem jego rozwojowi. Obrazy antycypacyjne, będące cechą wyższych poziomów rozwoju, choć nie wypływają tylko z obrazów reprodukcyjnych, to bazują na materiale w taki sposób wytworzonym. Wyobrażenia stają się antycypacyjne, czyli przyjmują postać wyobrażeń niepodlegających bezpośredniemu doświadczeniu, wówczas gdy kierują nimi operacje umysłowe, których rola polega na ujmowaniu tych przekształceń w aktach dynamicznych. Pojawia się nowy rodzaj obrazów jako że wraz z rozwojem intelektualnym uaktywnia się zjawisko umożliwiające kierowanie obrazami w umyśle, wprawianie ich w ruch - co oznacza budowanie obrazu (zjawiska, rzeczy, sytuacji, itd.) bez uprzedniego doświadczenia. To ważny mechanizm pozwalający zrozumieć zapatrywanie na to, czym jest np. instytucja, jaki jest do niej stosunek, jakie jest nią potencjalne zainteresowanie, nawet wtedy, gdy człowiek nie miał uprzednich doświadczeń z kontaktów z nią. Oczywiście nie jest to proces jednokierunkowy, nieodwracalny. Cechę obrazów antycypacyjnych stanowi zdolność do ich aktualizowania i wzbogacania. Oznacza to, że umysłowy obraz przedmiotów i zdarzeń może podlegać rozlicznym modyfikacjom, które proporcjonalnie do rozwoju zdolności umysłowych i afektywnych mogą rozwijać się w nowe obrazy, kształtować nowe wyobrażenia, To dynamiczny układ, charakteryzujący zresztą nie tylko rozwojowy potencjał dziecka, ale objawiający się w podobny sposób w postawach osób dorosłych. Nieodmiennie jednak u postaw kształtowania się tych obrazów leżą pierwsze spostrzeżenia dziecięce.

W toku rozmaitych doświadczeń dziecko, w stymulującym otoczeniu, przekształca pierwsze wyobrażenia. Jedne ulegają wzbogaceniu, sprofilowaniu lub poszerzeniu, inne spłycają się, a nawet zanikają pod wypływem na przykład czynników społecznych i oddziaływania grupy rówieśniczej (najczęściej zjawisko to obserwowane jest w grupach adolescentów). Niektóre z nich specjalizują się poprzez wprowadzenie mechanizmów kontroli wewnętrznej (np. wiedzy lub świadomości), inne pod wpływem czynników zewnętrznych (np. różnych form uczestnictwa w kulturze) 
współkształtują dojrzałe, świadome formy kulturalnej aktywności. Dlatego przyglądanie się specyficznym formom i etapom kształtowania się wyobrażeń dzieci powinno stać u podstaw zainteresowań badaczy zajmujących się zagadnieniami aktywności kulturalnej, uczestnictwa kulturalnego i innych form funkcjonowania w kulturze, a z pewnością tych, którzy projektują i realizują zadania skierowane w stronę publiczności instytucji kultury.

\section{4. „Żeby ludzie byli ciekawi” - metodolog̣iczne aspekty badań dziecięcej publiczności muzeów}

Przedmiotem szerszych badań, których analizy wykorzystano częściowo w niniejszym artykule, jest publiczność muzealna, a celem głównym próba ustalenia motywacji przedstawicieli tej populacji związanych $\mathrm{z}$ uczestnictwem $\mathrm{w}$ ofercie muzealnej. Znaczną część populacji poddawanej badaniom ${ }^{4}$ stanowiła grupa dzieci w wieku przedszkolnym, której członkowie odpowiadali na pytanie badawcze: Co to jest muzeum?

Do realizacji badań wybrano strategię jakościową. Metody jakościowe na polu nauk społecznych najczęściej kojarzone są z paradygmatem interpretatywnym. Badacze wykorzystujący tę strategię zainteresowani są bowiem nie tyle statystycznym ujęciem problemu, ile jego indywidualnym wymiarem, czyli tym, z jakim zjawiskiem mamy do czynienia, jak kształtuje się i wygląda określone zjawisko, dlaczego ono zachodzi, jakie skutki wywołuje. Prawomocne efekty tego badania dotyczą zatem zarówno opisu zjawiska, jak i jego charakterystyki ze względu na indywidualne zróżnicowanie, przyczyn powstawania oraz skutków. Strategiom jakościowym towarzyszą metody, wśród których z coraz większym sukcesem wykorzystuje się metody projekcyjne i inne z nimi współwystępujące, na przykład metodę zogniskowanych wywiadów grupowych. Przykładem tak zaprojektowanej strategii są badania dotyczące dziecięcych wyobrażeń na temat instytucji muzealnej przeprowadzone w grupie 250 dzieci uczęszczających do przedszkoli w województwie śląskim.

Poszukiwanie odpowiednich metod i narzędzi badawczych - zwłaszcza wtedy, gdy odnosi się je do pracy z dziećmi młodszymi - nastręcza wiele trudności. Dzieci nie potrafią odpowiadać precyzyjnie na pytania związane z definiowaniem pojęć i zjawisk. Dlatego odpowiedź wprost na pytanie o to, czym jest muzeum, nastręczałaby wiele trudności dzieciom, które nie umieją jeszcze precyzyjnie połączyć pojęcia z jego zawartością i znaczeniem [Przetacznikowa 1975]. W badaniach należało więc oprzeć się na takich sposobach wypowiedzi, które w sposób możliwie najczytelniejszy pozwalałyby odtworzyć obraz analizowanego zjawiska.

${ }^{4}$ Badania są w toku i dotyczą innych grup rozwojowych. Etap badań, do którego odnoszą się analizy i wnioski zaprezentowane w artykule, został zrealizowany od stycznia do maja 2018 roku. 
Pytanie o muzeum, implikujące co prawda odpowiedź o charakterze definicyjnym, wspierało się na psychologicznej wiedzy dotyczącej sposobów definiowania zjawisk charakterystycznych dla wieku przedszkolnego. W toku wieloletnich badań dowiedziono, że choć dziecięce definiowanie ma początkowo charakter subiektywny i egocentryczny, to już pod koniec wieku przedszkolnego można oczekiwać od dzieci wypowiedzi charakterystycznych dla późniejszych okresów rozwojowych. W definicjach, które ciągle jeszcze mają charakter opisowy, obok tych właściwości mających istotne znaczenie dla samego dziecka, pojawiają się szersze konteksty wkraczające w sferę innych, ponadjednostkowych doświadczeń społecznych. Dziecko opisuje zatem nie tylko te fragmenty, które subiektywnie są dla niego ważne, ale także takie, które z jakiegoś powodu ważne są dla innych, na przykład osób z otoczenia dziecka, w tym rodziców, nauczycieli, dziadków, rodzeństwa. W takich próbach definicyjnych dziecko sięga jednakże najgłębiej do obrazów mentalnych, które powstały w ramach dotychczasowej jego aktywności. Te ujawniają się w trzech postaciach: enaktywnej (gdy przeszłe zdarzenia reprezentowane są przez reakcje motoryczne), ikonicznej (odtwarzane $\mathrm{w}$ formie schematu obrazowego) oraz symbolicznej (wyrażające się w mowie i piśmie) [Bruner 1978]. W zależności od potrzeb i możliwości, czyli zewnętrznych i wewnętrznych uwarunkowań, może zostać wykorzystana każda z tych kategorii opisu form reprezentacji rzeczywistości.

Świat wyobrażeń dziecięcych najpełniej ujawnia się w zabawach tematycznych [np. Hurlock 1985], niemniej jedną z najczęściej wykorzystywanych form obserwacji tych wyobrażeń są rysunki dziecięce. W oczywisty sposób sięganie do aktywności rysunkowej dzieci w badaniach związane jest dziecięcymi zainteresowaniami tą formą aktywności artystycznej. Co równie istotne, wraz z doskonaleniem się praksji, dzieci w wieku przedszkolnym opanowują nowe umiejętności gestyczne i potrafią wypowiadać się w formie graficznej - rysunkowej. Zatem ich rysunki z upływem czasu stają się coraz wyraźniejszą formą ujawniania swoich wyobrażeń o świecie, a analiza tych wytworów pozwala nie tylko zorientować się w tym, co dziecko wie na temat badanego fragmentu rzeczywistości, ale także określić stosunek emocjonalny do niej. Wartość prac rysunkowych dzieci pod koniec okresu przedszkolnego polega na umiejętności opisowego ukazywania zarówno przedmiotu, jak i jego pojęcia - rysunki stają się ikoniczną reprezentacją przeżyć i wiedzy o świecie [np. Gloton, Clero 1985, Przetacznik-Gierowska 1993] $]^{5}$ Z pomocą rysunku

każde spostrzeżenie, przeżycie, a w konsekwencji ustosunkowanie osoby do innych lub do siebie samego jest projekcją, ponieważ jest rzutowaniem świata prywatnego danej osoby na obiektywny stan rzeczy [...] zaś walorem otrzymanych drogą analizy rysunku danych o dziecku jest fakt, że wykraczają one poza deklaratywny charakter informacji uzyskiwanych na

${ }^{5}$ Z tego powodu analiza twórczości rysunkowej dziecka jest jedną z najważniejszych technik badania dojrzałości pojęciowej [np. Hornowska, Paluchowski 1987] 
drodze tradycyjnie stosowanych metod badań. Umożliwiają badanie procesów częściowo lub w całości nieuświadomionych” [Kostrubiec, Mirucka 2007: 8].

Biorąc pod uwagę takie cechy wypowiedzi rysunkowych można je traktować jako techniki projekcyjne, które, zgodnie z definicyjnymi ujęciami Józefa Rembowskiego, są sposobem rzutowania treści własnej psychiki - wydobywają z niej akcenty szczególnie silne, dominujące zarówno obrębie stanów emocjonalnych, jak i wiedzy [Rembowski 1986].

Wypowiedziom graficznym dzieci towarzyszą zwykle komentarze słowne. Swobodna ekspresja słowna obserwowana w tej grupie rozwojowej sprzyja budowaniu przekazów symbolicznych za pomocą mowy. Nie bez znaczenia dla kształtowania się owych przekazów pozostają otoczenie, z którym dziecko się komunikuje, oraz opanowanie zwrotów językowych i umiejętność odtwarzania opinii zasłyszanych u osób dorosłych. Dziecko chętniej wypowiada się w otoczeniu osób, które wcześniej poznało, a także, z niemałą radością, reprodukuje opinie i zwroty, których nauczyło się w innych sytuacjach od dorosłych. Biorąc pod uwagę tę skłonność do wypowiadania się dzieci oraz specyfikę badań jakościowych, w dalszych analizach wykorzystano metodę zogniskowanych wywiadów grupowych ${ }^{6}$. Wywiady przeprowadzono $\mathrm{z}$ dziećmi w grupach (łącznie 8 grup), których liczebność wahała się do 5 do 8 osób. To wystarczająca liczba do prowadzenia w miarę swobodnej rozmowy z dziećmi, których spontaniczne reakcje (np. ruchowe) zakłócają przebieg rozmowy. Czas trwania wywiadu określany był zgodnie z Szumanowską kategorią czasu wystarczającego [Szuman 1990] - czyli takiego, którego kres wyznaczało dziecięce znużenie. W kategorii czasu, zarówno dotyczącej zadań rysunkowych, jak i wywiadów znaczenie miał ogólny czas prowadzenia badań. Zgodnie z przytoczonymi wcześniej uwarunkowaniami kształtowania się pamięci w wieku przedszkolnym, wprowadzono kategorię odroczenia czasowego, związanego z zachowaniem odległości czasowej od wizyty muzealnej i pozwalającego w pełni wykorzystać zjawisko reminiscencji. Pytania moderatora koncentrowały się wokół czterech problemów ujętych w pytania zrozumiałe dla dzieci:

1. Co to jest muzeum i po co ono zostało zbudowane?

2. Z kim się chodzi do muzeum?

3. Co się robi w muzeum?

4. Co w muzeum dziecku się podoba, a co się nie podoba?

${ }^{6}$ To metoda badań stosowana często w strategii badań jakościowych, których istota kryje się nie w generalizacji, ale w zrozumieniu mechanizmów (indywidualnych) rządzących danym problemem. Metoda zogniskowanych wywiadów grupowych polega na dyskusji w gronie kilku osób, skoncentrowanej na wybranym przez moderatora temacie, i zakłada nieustrukturyzowany sposób pozyskiwania informacji (chociaż nie należy mylić jej z wywiadem swobodnym). W celu uzyskania informacji stosuje się wcześniej opracowany ramowy scenariusz moderacji uwzględniający główne zagadnienia interesujące badacza [Maison 2001, Lisek-Michalska, Daniłowicz 2004]. Wypowiedzi wszystkich członków grupy są rejestrowane, a następnie odsłuchiwane. 
W efekcie badań uzyskano ponad dwugodzinną rejestrację wypowiedzi jako materiał do dalszych analiz.

Rysunek jako technika badawcza, w przypadku pytania dzieci o zjawiska i definicje, okazał się najwłaściwszym narzędziem badań, pozwalającym na odtworzenie tych fragmentów wiedzy, doświadczeń, spostrzeżeń i opinii dzieci, których one same nie potrafią zwerbalizować. Nie oznaczało to rezygnacji z wypowiedzi słownych. $\mathrm{Z}$ doświadczeń badawczych wynika jasno, że te dwie metody pozyskiwania danych w przypadku dzieci młodszych powinny występować wspólnie, niwelując ewentualne nieodpowiedzenia wynikające ze stosowania którejkolwiek z metod osobno. Ich jednoczesne zastosowanie niweluje ewentualne fałszywe sposoby odczytywania danych. W badaniach dzieci młodszych łączenie wypowiedzi rysunkowej z werbalną okazało się bardzo skutecznym sposobem pozyskiwania danych. To doświadczenia nienowe. Już Piaget i Inhelder [1967] stosowali analizy rysunków, wypowiedzi słownych i gestów w celu poznania odtwarzanych obrazów umysłowych. Po części doświadczenia te znalazły wsparcie w badaniach Allana Paivio, który zakładał różne sposoby kodowania informacji i doświadczeń jakie docierają do człowieka ze świata zewnętrznego. Podstawą takiego rozróżnienia było przekonanie, że wszelkie doświadczenia mają charakter słowny i pozasłowny ${ }^{7}$ [Paivio 1991]. Tak więc pytanie badawcze, szczególnie w odniesieniu do dzieci, powinno zakładać co najmniej te dwie możliwości udzielenia odpowiedzi, tym bardziej że każdy system może być aktywny bez drugiego i funkcjonować w pełnej zgodności co do przekazu treści, choć w różnej formie.

\section{Analiza materialu badawczego - wnioski wstępne}

Wyniki badań służyły poznaniu wyobrażeń na temat muzeum jakie noszą dzieci w wieku 5-7 lat, co oznaczało wyłonienie tych elementów i fragmentów wyobrażeń, które wpływają na kształtowanie się pojęcia muzeum. W wyniku badań uzyskano bogaty materiał badawczy, w tym 250 rysunków oraz ponad dwugodzinny zbiór wypowiedzi dzieci uczestniczących w badaniach typu fokusowego. $Z$ analiz tego materiału wyłaniają się interesujące wnioski, które można podzielić na cztery obszary tematyczne.

Warto zacząć od ogólnego wrażenia, jakie wyłania się ze wszystkich wypowiedzi - dzieci dysponują pozytywnym wyobrażeniem na temat muzeum. Bez względu na to, jakiego typu jest to placówka, jakie zbiory i w jakiej formie prezentuje, dzieci prezentują pozytywne wyobrażenie o owej instytucji. Warto podkreślić, że nie zawsze

7 W analizach Allana Paivio pojawia się przekonanie, że istota informacji symbolicznej rozkłada się na imageny (niewerbalne wyobrażenia) oraz logogeny, specjalizujące się w jednostkach lingwistycznych oraz wytwarzaniu mowy. Co ważniejsze, oba systemy są niezależne, mogą zatem wzbogać się wzajemnie, ale nie są sobą warunkowane. 
są to wyobrażenia stanowiące pochodną czynności zwiedzania. Niektóre z badanych dzieci nie były nigdy wcześniej w muzeum, stąd ich wyobrażenia zbudowane są z opinii innych na temat muzeum, a nierzadko opierają się na informacjach medialnych.

Pozytywny obraz instytucji można odnaleźć w sposobach konstruowania wypowiedzi rysunkowej. Prace dzieci uczestniczących w badaniu charakteryzują się bogatą kolorystyką - do ich sporządzania dzieci wykorzystywały pełną dostępną im gamę kolorystyczną. Rysunki wykonywane są pewną kreską, a wiele pól wypełnionych jest kolorem. W treści prac pojawiają się uśmiechnięte postaci trzymające się za ręce, a ich sylwetki wzbogacone są wielką ilością szczegółów. Wszystkie te elementy poświadczają zainteresowanie dzieci tematyką rysunku, a także pozytywne do niej nastawienie. Oczywiście można zastanawiać się, czy to sam fakt wykonywania rysunku, czy jego tematyka są ważniejsze. Jak wynika z przytoczonych wcześniej analiz, ekspresja dziecięca, bez względu na stosowaną technikę, jest odbiciem myśli i odczuć dziecka względem problemu, który podejmuje w swojej pracy. Zatem i w tym przypadku nie można rozdzielać tych wartości.

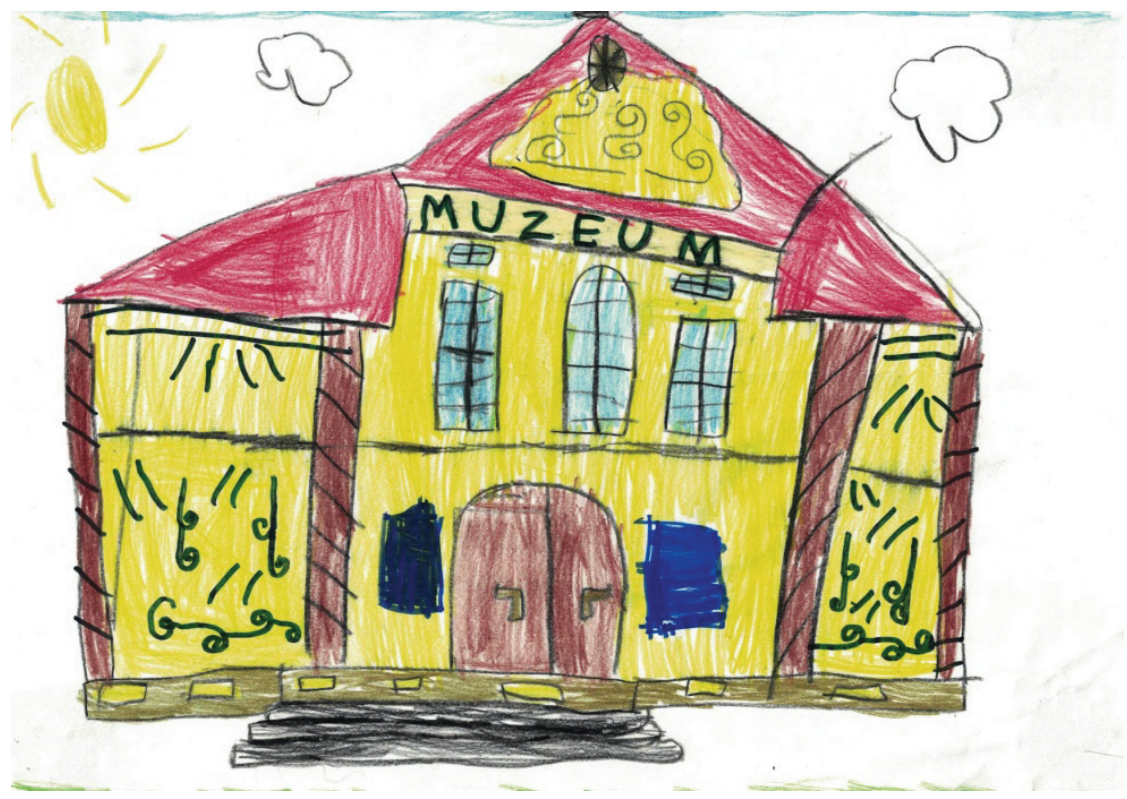

Rys. 1. Konrad, lat 6, Muzeum współczesne.

Wystawa odbyła się w Muzeum Śląska Cieszyńskiego w ramach 11. Nocy Muzeów w 2018 roku (25 maja) 


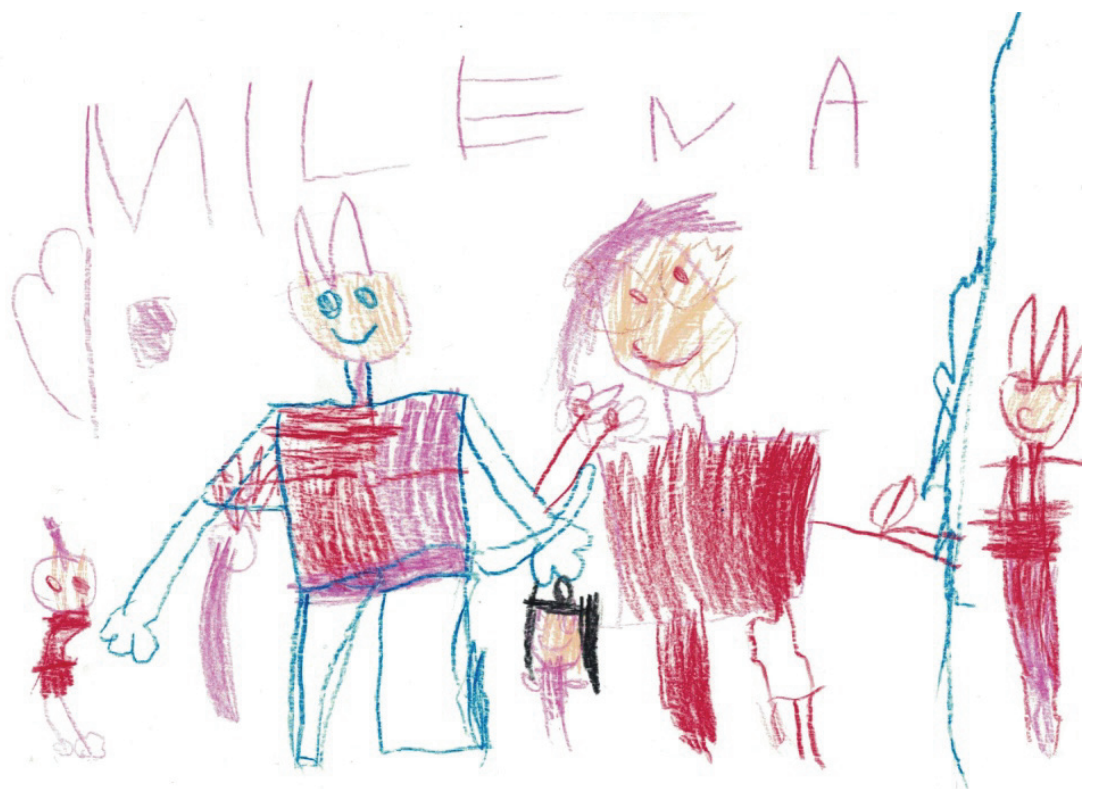

Rys. 2. Milena, lat 5, Rodzina w muzeum i przewodnik.

Wystawa odbyła się w Muzeum Śląska Cieszyńskiego w ramach 11. Nocy Muzeów w 2018 roku (25 maja)

Głębsze odczytanie przekazu, jaki kryje się za dziecięcymi pracami, umożliwiają wypowiedzi zarejestrowane w trakcie wywiadów. W wypowiedziach słownych dzieci muzeum jawi się im początkowo jako budynek: „Taki duży budynek; taki duży jest, ogromny i schody są na górę i tam są różne rzeczy”. Te „różne rzeczy” najczęściej są „stare, gdzie są skamieliny; różne kogoś pamiątki”; a nawet: „Muzeum to jest takie coś, że tam trzymają wszystko, co wiedzą". Skojarzenie muzeum i biblioteki (zresztą nie jedyne) jest w tych wypowiedziach aż nadto oczywiste. „Rzeczy” w muzeum są dla dzieci nośnikami wiedzy (ta konstatacja pojawi się raz jeszcze w kolejnych wypowiedziach), a ich układ "na półkach takich specjalnych” potwierdza związki tych instytucji, które wywodzą się z tradycji aleksandryjskiej. W wypowiedziach łatwo można zauważyć jedną prawidłowość - muzeum w opinii dzieci jest zwykle dużym, zatem poważnym budynkiem, w którym przechowuje się przedmioty o wielkiej wartości (historycznej), ważne dla zachowania pamięci, i jest ich dostatecznie dużo, aby wypełnić ogromne sale, gdzie mogą pomieścić się liczni zwiedzający. Ten sposób myślenia można odnaleźć w ostatniej z zacytowanych tu wypowiedzi: „Muzeum zbudowali dlatego, że bardzo dużo różnych rzeczy znaleźli i nie mieli gdzie to

${ }^{8}$ Związek ten motywuje Régis Debray we Wprowadzeniu do mediologii [Debray 2010]. 
postawić, bo dom był chyba za chudy i z tego budowniczy ci, którzy znaleźli i mieli za chudy dom to budowników zaprosili, żeby zrobili im muzeum, żeby było bardzo grube, żeby się zmieściły wszystkie rzeczy”.

Wstępne wrażenia z ogólnych analiz zostały pogłębione. W ich wyniku udało się wskazać wyraźne sposoby myślenia o muzeum, które w grupie badanych dzieci utożsamiane było z instytucją, muzealium (eksponatem), ekspozycją i wreszcie przestrzenią społecznych relacji. Warto zaprezentować przykłady tego typu wyobrażeń.

$\mathrm{Z}$ analiz rysunków wynika jasno, że pewna grupa dzieci wyobraża muzeum jako poważną, monumentalną wręcz instytucję. Takie ujęcia pojawiły się w rysunkach odnoszących się do muzeum jako formy architektonicznej. Przeważały tu wizerunki sugerujące zabudowę pałacową, zamkową lub fantastyczną. To naturalne skojarzenie, któremu towarzyszyły na domiar epitety „starości” i „dawności”. To symptomatyczne, dzieci w żadnej z wypowiedzi rysunkowych nie łączyły pojęcia muzeum z nowoczesną formą architektoniczną, która wydaje się mocniej odpowiadać na potrzeby współczesnej publiczności, chociażby pod względem udogodnień fizycznych. Próby oddania dawnej, historycznej formy architektonicznej przybierały zaś w pracach dzieci najbardziej przystającą do tego wyobrażenia formę zamkowo-pałacową. Kategoria „starości” nie tylko odnosiła się zatem do kolekcji muzealnej, ale obejmowała także zewnętrzną formę budynku.

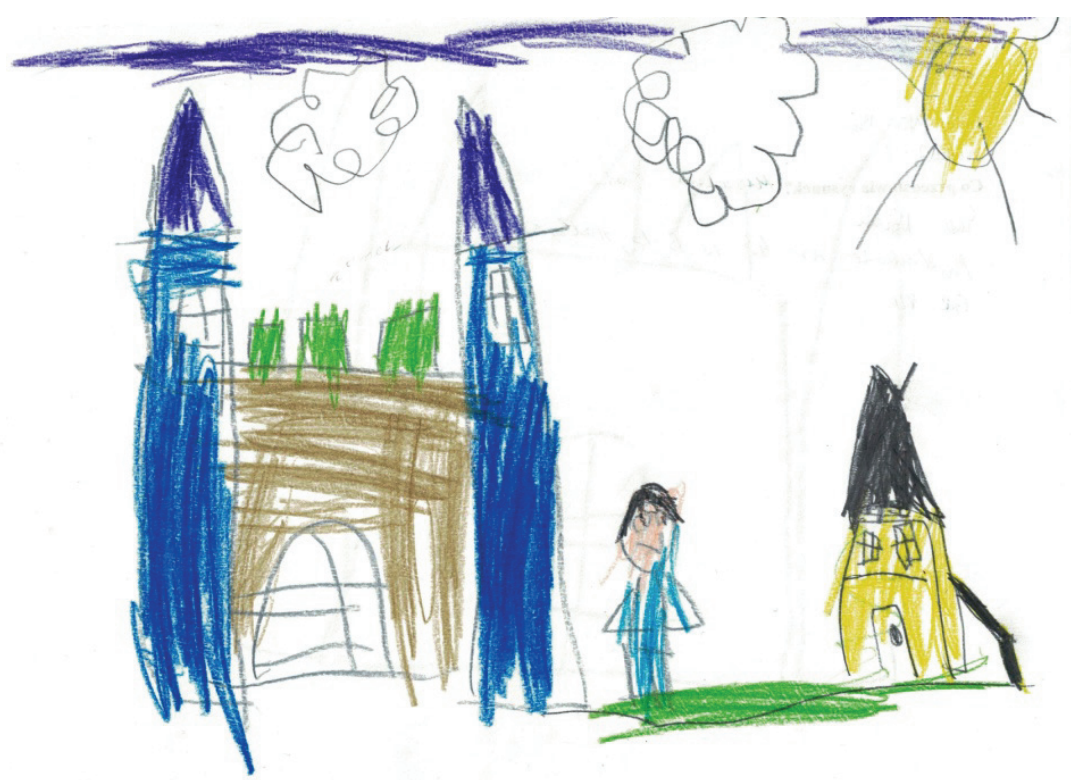

Rys. 3. Mateusz, lat 7, Muzeum.

Wystawa odbyła się w Muzeum Śląska Cieszyńskiego w ramach 11. Nocy Muzeów w 2018 roku (25 maja) 


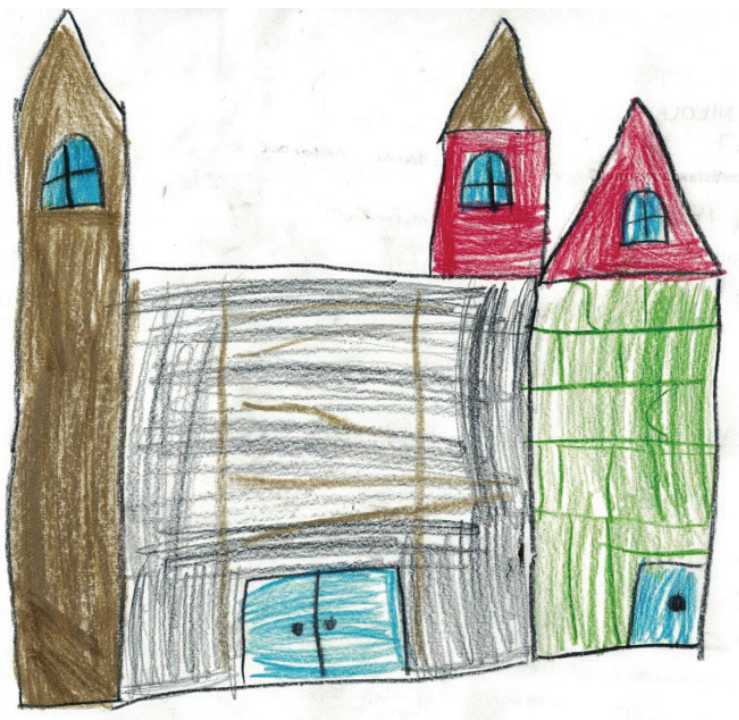

Rys. 4. Nikola, lat 7, Muzeum.

Wystawa odbyła się w Muzeum Śląska Cieszyńskiego w ramach 11. Nocy Muzeów w 2018 roku (25 maja)

W innych wyobrażeniach, choć mniej licznie reprezentowanych, można było zauważyć odniesienie do bryły rodzinnego domu z drzwiami, oknami, spadzistym dachem, nawet kominem. Łączenie tej formy z pojęciem muzeum mogło sugerować, że w wyobrażeniach dzieci muzeum jest miejscem im sprzyjającym, przestrzenią niemal domową. Taka mogłaby przesądzać o sposobach kontaktu z muzeum. W wypowiedziach swobodnych wnioski te nie znalazły uzasadnienia. Dzieci częściej kojarzyły muzeum z pałacem i zamkiem, nie odwołując się do pojęcia domu. Można zatem domniemać, że bryła przypominająca dom jest po prostu jedną z form architektonicznych, które dziecko kojarzy w jakiś sposób z muzeum ale wobec nieporadności graficznej lub braku pomysłu na jej odmalowanie dzieci przywołały „przeskalowaną” formę bryły budynku mieszkalnego. W tym przypadku nie funkcja ale skala budynku okazywała się ważna - postaci ustawione w bliskości tego „domu” są bowiem stosunkowo małe. Muzeum we wszystkich niemal pracach kojarzono z dużym, wręcz monumentalnym budynkiem, co pośrednio wskazywać miało na rangę tej instytucji. W pracach dziecięcych o znaczeniu decyduje bowiem wielkość, ta zaś nie wynika ze stosowania zasad perspektywy, ale wyraża stosunek emocjonalny do postaci lub przedmiotu. Stąd płynie czytelny komunikat - jeśli coś jest duże, jest ważniejsze od tego, co jest małe. 


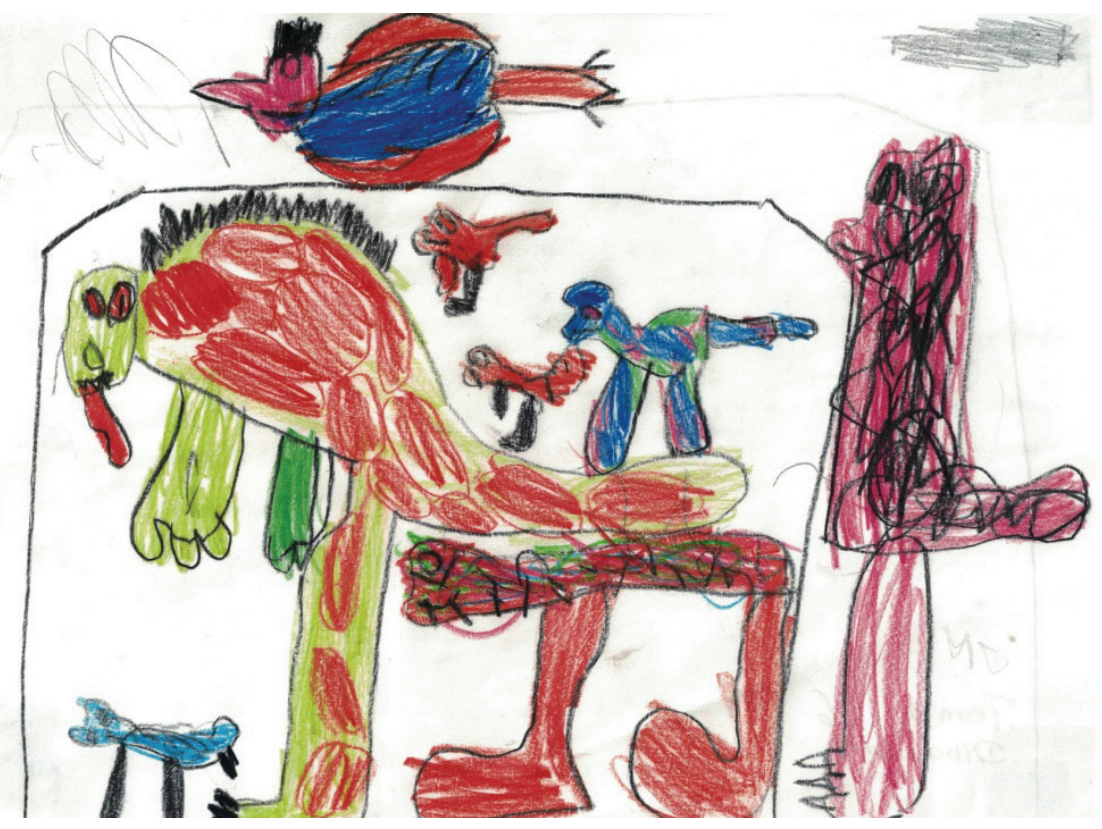

Rys. 5. Tomek, lat 6, Muzeum.

Wystawa odbyła się w Muzeum Śląska Cieszyńskiego w ramach 11. Nocy Muzeów w 2018 roku (25 maja)

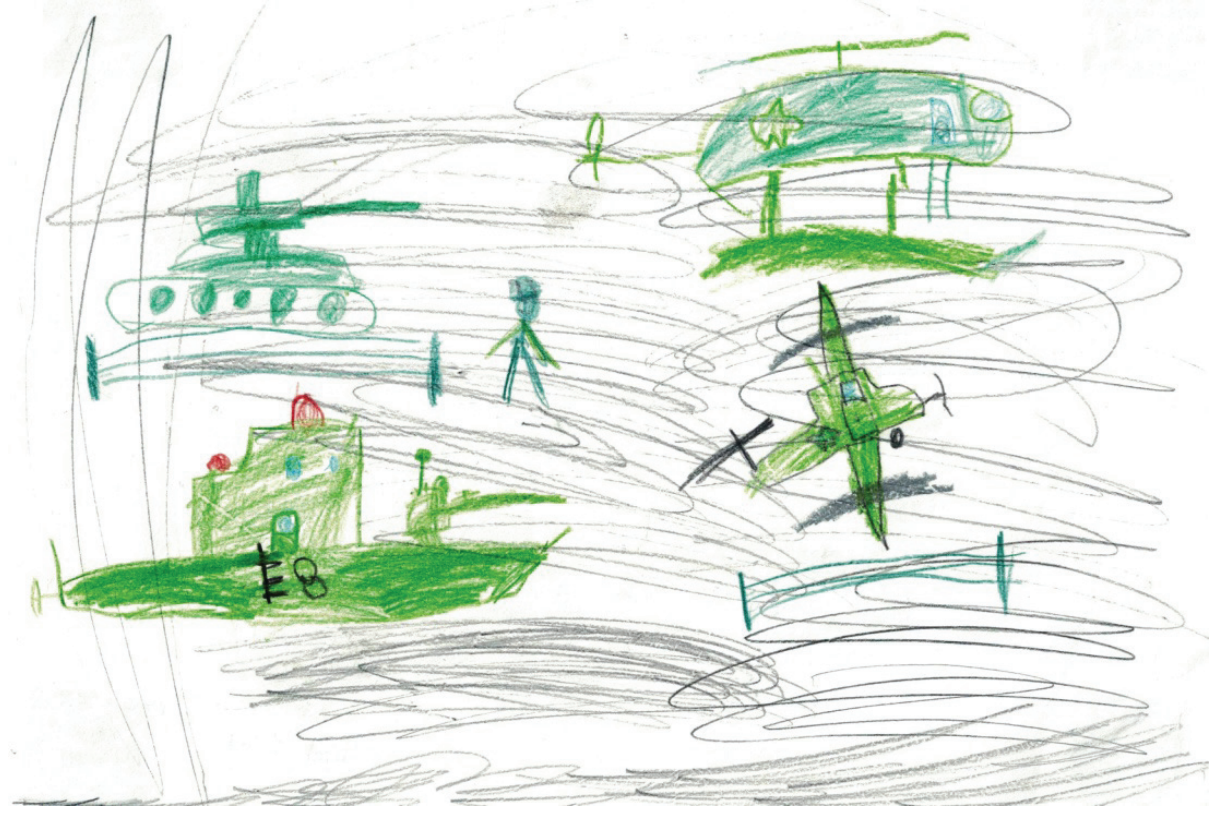

Rys. 6. Karol, lat 6, Muzeum.

Wystawa odbyła się w Muzeum Śląska Cieszyńskiego w ramach 11. Nocy Muzeów w 2018 roku (25 maja) 
W drugiej grupie rysunków pojawiają się charakterystyczne dla instytucji muzealnej eksponaty - muzealia. Dzieci zatem identyfikują muzeum już nie tylko z bryłą architektoniczną, ale też z jej zawartością. Znamiennym dla analizowanych prac jest fakt, że zaledwie na dwóch pojawiają się prace artystyczne - rzeźby i malarstwo. Dzieci utożsamiają muzeum najczęściej z wystawą klasycznych muzealiów, skamielin, narzędzi i przedmiotów, jak same określają „pochodzących ze starych czasów”. W grupie eksponatów, największe i najbardziej szczegółowe rysunki dotyczą zbiorów archeologicznych, w tym skamielin - pozostałości prehistorycznych zwierząt. „Dinozaury” to kluczowe elementy przedstawień rysunkowych. Szczególne zainteresowanie tą tematyką wyraźniej widać w szczegółach z jakimi dzieci odwzorowują fragmenty i całości szkieletów zwierzęcych.

Na kształt prac rysunkowych wyraźnie wywierają wpływ emocje - dzieci z wielkim pietyzmem odmalowują te doświadczenia, które wywoływały u nich zaciekawienie i jednocześnie lęk. Opisując w trakcie wywiadów muzealia, wielokrotnie podkreślały cechy wielkich gadów prehistorycznych, używając skojarzeń z „bestiami”, „wielkimi dinozaurami”, „strasznymi potworami”. Z drugiej strony najczęściej opisywały szczegóły: „ostre kły”, „długie nogi”, „wielkie zęby”, „olbrzymie głowy i łapy”. Dzieci omawiające poszczególne eksponaty lub przedstawiające je na ilustracjach przyjmowały postawy badaczy bacznie obserwujących obiekt swoich zainteresowań.

Również z analiz wywiadów można wywieść upodobania dzieci. W wypowiedziach przywołują: „Duże kości, patrzy się na kości dinozaurów; podobało by mi się jakby były prawdziwe dinozaury". Inne preferują zbroje, atrybuty władzy królewskiej („złotą koronę”), a także szaty: „różne ubrania tych, którzy szli na wojnę, tych którzy chodzili po starym mieście” - „W muzeum jest najfajniejsze to że, na przykład można oglądać różne rzeczy z bliska, na przykład szaty królewskie”. A co ważniejsze, dzieci wolą oglądać „takie te [zapewne zabytki - J.S.], a nie nowoczesne”. W szystkie wzbudzają jednocześnie ich zainteresowanie i grozę: „,jak są takie wielkie i kościotrupowe...; takie szkielety straszne, i kości”.

Zarówno w warstwie rysunkowej, jak i opisowej trudno pozbyć się wrażenia, że obok zainteresowania lęk wzmocnił ślad pamięciowy i zdominował wyobrażenie o muzeum skojarzone ze skamieniałą formą wielkiego dinozaura. Jeśli w przypadku prac rysunkowych dzieci samodzielnie poszukiwały odpowiednich form dla przedstawień swoich wyobrażeń o muzeum, to w wywiadach wyraźnie widać było wzajemny wpływ opowieści. Zarówno ten dotyczący ekspozycji, jak i taki, który uruchomił pamięć o zagrożeniach, jakie potencjalnie wywołuje wizyta w muzeum. Skojarzenie z kośćmi w tym przypadku było symptomatyczne. Dzieci z niezwykłą umiejętnością kształtowania zaskakujących połączeń pomiędzy skojarzeniami od szkieletu dinozaura przechodziły do ludzkich szkieletów, które w ich opinii mogły im zagrażać, na przykład wówczas, gdyby się przewróciły na zwiedzających, lub w przypadku, gdyby się okazało, że to szkielet „rodzinny”. O ile więc „,stary” budynek wywoływał skojarzenia pogodne lub przywoływał powagę instytucji, o tyle muzealia 
były opisywane w kategoriach ujawniających zainteresowania dzieci, typu: „mnie się podobały stare samochody, bo się nimi interesuję" lub wywołujące strach: „te stare rzeczy są trochę straszne... bo są starożytne; kości są straszne”.

$\mathrm{Z}$ powyższymi wypowiedziami łączyła się naturalnie kolejna grupa prac rysunkowych. Jeśli we wcześniejszych wypowiedziach rysunkowych i werbalnych mieściły się odniesienia tylko do muzealiów, okazów i przedmiotów o znaczeniu historycznym, to w kolejnych wyraźnie widać ekspozycję jako ciąg przedmiotów, narzędzi i urządzeń służących do celów wystawienniczych. Można odnaleźć gabloty, łańcuchy podtrzymujące eksponaty, podesty i stoły. Na rysunkach pojawiają się zatem różne formy organizacji ekspozycji ale także inne przedmioty pozostające bez związku merytorycznego z ekspozycją. Nierzadko w rysunkach można odróżnić sprzęty, narzędzia lub wyposażenie sal wystawowych. Uwagę dzieci zwracają więc wyłączniki światła, oświetlenie, ławki, krzesła, gaśnice, kontakty elektryczne, a nawet rury kanalizacyjne. Już wspomniano wyżej, dzieci są bystrymi obserwatorami. W muzeum, obok eksponatów, innych osób obserwują różne narzędzia: „czasami są takie słupki i takie liny; tam wiszą takie szafy... ale jak one wiszą?”; lub: „tam jest taki guzik, i jak pani taka naciśnie to się zamyka krata..., a jakby mnie tam zamknęło".

Obok klasycznego wizerunku miejsca wystawienniczego, muzeum jawi się dzieciom zatem jako miejsce pracy z pełnym wyposażeniem. Jest instytucją, w której wykorzystuje się rozmaite narzędzia do wykonywania pracy muzealnika (najczęściej postać skojarzy się z osobami oprowadzającymi lub pilnującymi ekspozycji). Jako że trudno wskazać atrybuty przewodnika muzealnego, w przedstawieniach rysunkowych dzieci odtwarzają przedmioty, które obiektywnie miałyby służyć wykonywaniu takiego zawodu. Muzeum w tej grupie przedstawień jest miejscem, w którym eksponuje się zbiory (to naczelna funkcja - upowszechnieniowa, trafnie rozpoznawana przez dzieci), a za ich ekspozycję i pracę w ich otoczeniu odpowiedzialne są specjalne służby, którym trudno przypisać jakieś konkretne zadania.

Wszystkie elementy ekspozycji, i te rzeczywiście zauważone, i te wyobrażone, podsuwają dzieciom pomysły, które wykorzystują w dyskusjach. Dzieci, z jednej z grup, pytane o to, co w muzeum im się szczególnie podoba, w miejsce odpowiedzi wdały się w poważną wymianę zdań. Wskazując, że najciekawsze były skamieliny, mówiły dalej: „Takie rzeczy były w dawniejszych czasach; ale w dawniejszych czasach nie było prądu, więc jak one miały się stać? Był prąd! Nie, nie było. Przecież zawsze musi być prąd, bo inaczej nie ma światła. Nie było. Były świece. Albo było, jak to się nazywa - słońce. Była metoda jak nie było zapałek to tarło się dwa patyki”. Taka dyskusja to już niemal lekcja muzealna. 

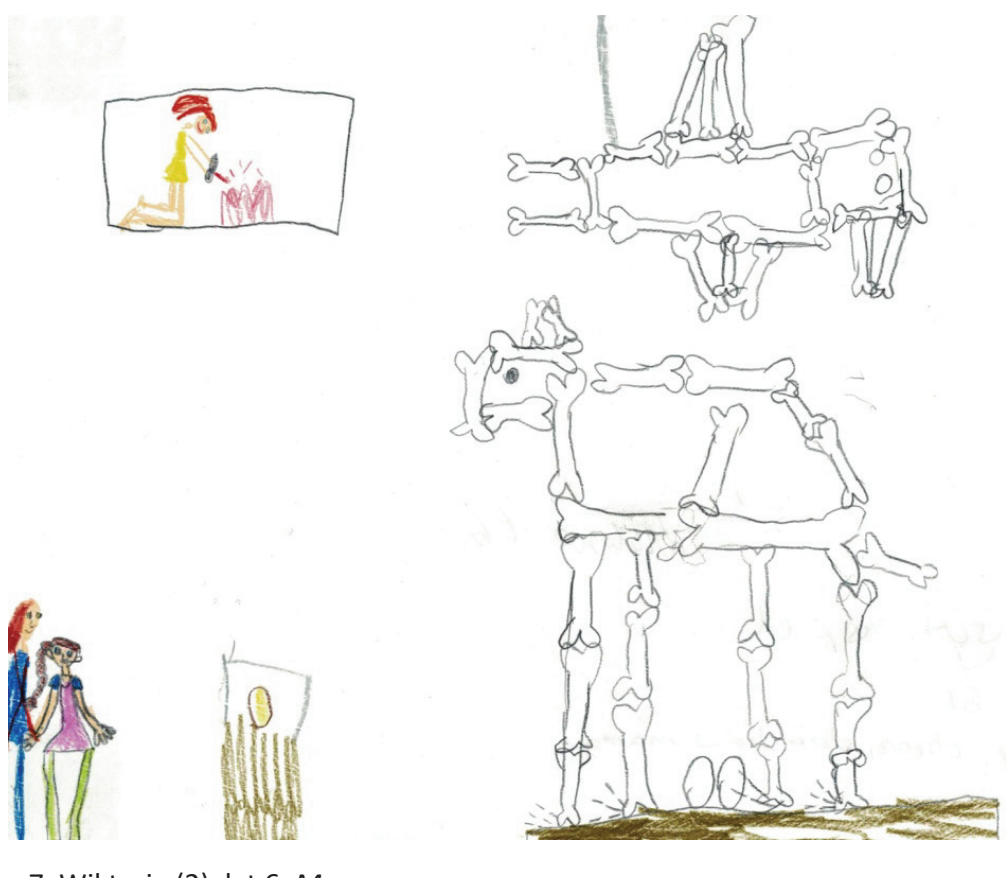

Rys. 7. Wiktoria (2), lat 6, Muzeum.

Wystawa odbyła się w Muzeum Śląska Cieszyńskiego w ramach 11. Nocy Muzeów w 2018 roku (25 maja)

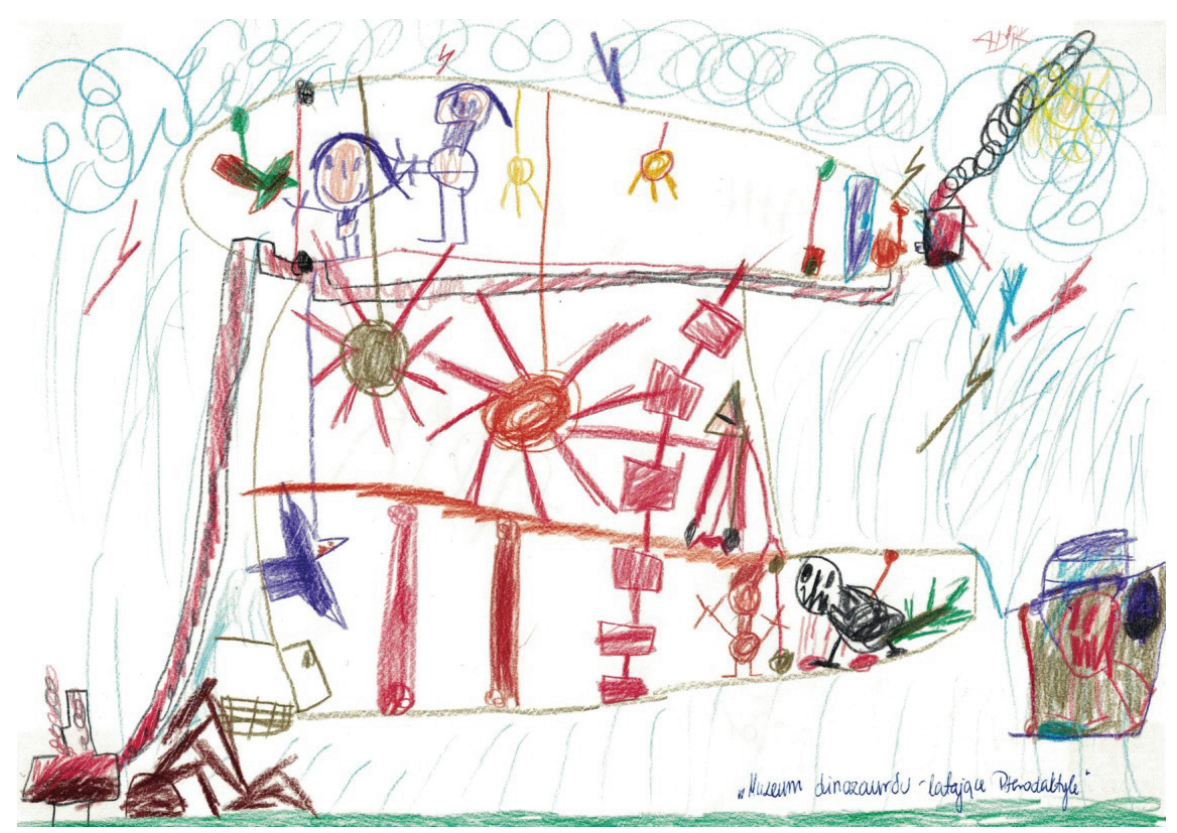

Rys. 8. Adrian, lat 7, Muzeum dinozaurów - latajq̨ce Pterodaktyle.

Wystawa odbyła się w Muzeum Śląska Cieszyńskiego w ramach 11. Nocy Muzeów w 2018 roku (25 maja) 
W tej grupie analiz warto przytoczyć także te wypowiedzi, które zawierają konkretne wyobrażenia społecznej funkcji muzeum. W odpowiedziach na pytanie o to, "po co jest muzeum”, pojawiły się bardzo interesujące sformułowania: „Muzeum jest po to, żeby można zobaczyć, co kiedyś było. Że nie było tylko wtedy, co teraz jest”; - „żeby o tym nie zapomnieć, żeby pamiętali jak było dawniej” - „Po to, żeby dzieci mogły sobie zobaczyć, sobie wyobrazić jak te rzeczy były używane, jak te rzeczy oglądano, jak dawno one ruszały się, jak dawno spali, jak dawno pili, jak dawno wszystko robili” - „żeby ludzie widzieli jak było w dawnych czasach ci co ani jednej wojny nie przeżyli”. Te wyraźne cele poznawcze przełamane zostały odpowiedziami sugerującymi inne funkcje muzeum: „Żeby się bawić” - „żeby mieć zajęcia, żeby się nie nudzić” - „żeby dobrze spędzić czas w wakacje”. I z tych wypowiedzi można wyłonić społeczne funkcje muzeum, które obok zadań edukacyjnych powinno sprzyjać różnym formom spędzania wolnego czasu, w przypadku dzieci, w otoczeniu rodziny i najbliższych: „Żeby rodzina przyszła się dowiedzieć różnych rzeczy na temat jak było w wojnie, jak powstały czołgi i jak wyglądały kiedyś karabiny i czołgi” - „i żebyśmy byli szczęśliwi”.

Dzieci kojarzą wizyty w muzeum z obyczajem rodzinnym. Mówią: „idę do muzeum z mamą i z tatą, i z rodzicami, i z bratem, i z siostrą, albo z babcią i z wujkiem, albo z dziadkiem, i z ciocią"; inne dodaje: „jak jest mama i tata, i wujek, i ciocia, albo babcia i dziadek, to może być mały też w muzeum. Pod opieką dorosłego, bo mali też chcą pooglądać pradawne rzeczy. Każdy młody jest ciekawy". Ważne, aby dziecku towarzyszył dorosły - duży: „z takim wielkim, bo z takim małym to nie idzie się”. W odpowiedzi na pytanie, dlaczego, dziecko argumentuje: „No bo same takie małe dzieci nie mogą. Bez rodziców one uciekną i tak się zgubią i może je auto przejechać; albo: tam może być ślisko i ktoś się poślizgnie, przewróci się i tak pojedzie i rozwali se głowę, jeszcze ten kościotrup się na niego przewali”. Dorosły, a w niektórych wypowiedziach przewodnik (kryjący się pod określeniem „pan kierownik") jest niezbędnym towarzyszem zwiedzania muzeum odpowiadającym na jego potrzebę zapewnienia bezpieczeństwa. I nie tylko o śliską podłogę tu chodzi: „One [dzieci - J.S.] nie rozumieją zasad muzeum” - przekonuje jeden z uczestników badania. Ponadto nowe miejsce, nowa sytuacja, nowe sposoby funkcjonowania wywołują u dziecka lęk, a ten może zniwelować tylko taka osoba, do której dziecko ma bezwzględne zaufanie. Co warte podkreślenia, nierzadko środkiem zastępczym jest ulubiona maskotka lub przedmiot. W opinii jednego z dzieci do muzeum chodzi się z „małpką - zabawką”. Te wypowiedzi wypełniają czwartą grupę wyobrażeń, jakimi dysponują dzieci przedszkolne. $\mathrm{W}$ tej ostatniej (wstępnie wyodrębnionej) grupie wypowiedzi rysunkowych i słownych można odnaleźć cały szereg skojarzeń instytucji muzealnej traktowanej jako przestrzeń społecznych relacji. W rysunkach dzieci odwzorowano całe spektrum interakcji, jakie odbywają się między zwiedzającymi: są grupy w towarzystwie przewodnika, rodziny z dziećmi, schematy sugerujące rozmowę dwóch osób skupionych na eksponacie, są postaci oglądające ekspozycję 
i przechodzące pomiędzy gablotami. Jednak na całościowo pozytywny obraz muzeum to emocje, jakie dzieci odmalowują w swoich pracach. Podobnie jak w opisie ogólnej tendencji ocenianej instytucji, tak na rysunkach przywołujących społeczne funkcje muzeum dzieci rysowały postaci uśmiechnięte, wiele z nich ma wyciągnięte w kierunku innych osób dłonie, twarze zwrócone są w stronę innych osób. Postaci są narysowane dość szczegółowo, kolorową kreską. Społeczne sytuacje odtworzone na rysunkach cechuje aura zadowolenia, znamionuje je dążenie do pozostawania w kontakcie z innymi oraz żywotność przedstawienia.

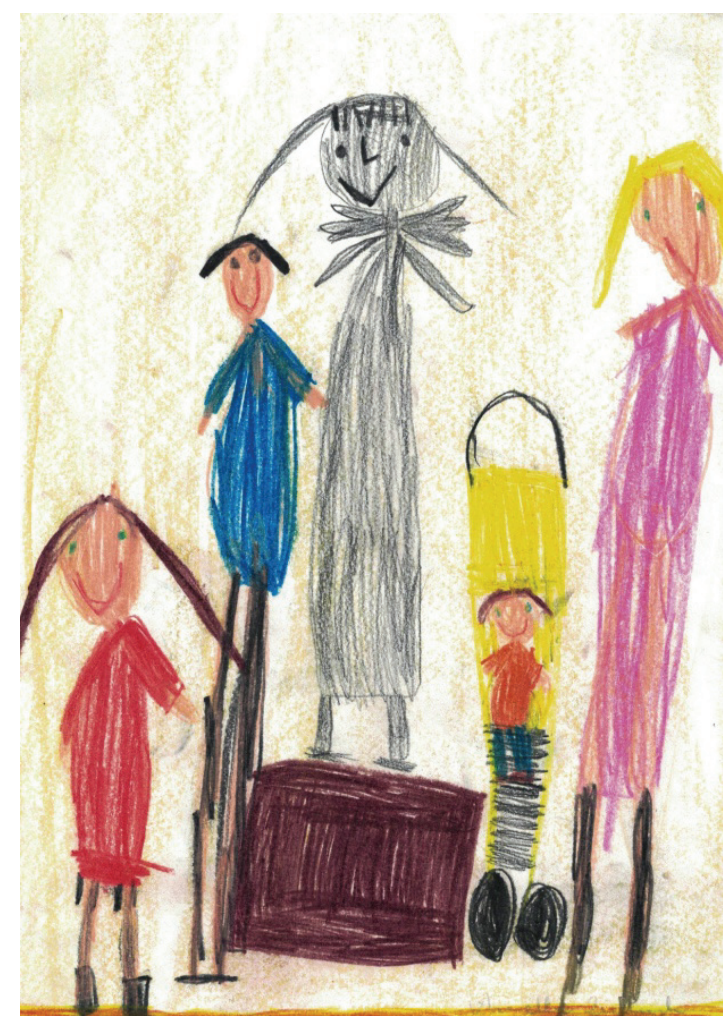

Rys. 9. Amelia, lat 6, Muzeum.

Wystawa odbyła się w Muzeum Śląska Cieszyńskiego w ramach 11. Nocy Muzeów w 2018 roku (25 maja)

W wypowiedziach ten społeczny aspekt zwiedzania wybrzmiewa jeszcze mocniej. Dzieci są świadome, że w dużej, zatem poważnej instytucji, nawet wówczas, gdy się ją odwiedza w przyjaznym towarzystwie, obowiązują zasady zachowania się inne niż potocznie przyjęte. Mówią: „Ogląda się pamiątki, ale się ich nie dotyka bo mogą spadnąç” - „Cicho się zachowywa; nie pije się" - „Nie wolno dotykać jakichś rzeczy i na przykład też mogą się szybko rozmazać, bo ktoś może mieć brudne ręce 
albo tłuste” - „Jak ktoś myje podłogę to nie można wejść na podłogę, bo można się poślizgnąć na jakąś rzecz” - „Jak ktoś idzie w jedną stronę i w drugą stronę to można się przewrócić"; a: „Jak będzie tajemne wejście to wtedy tam nie wolno wchodzić, bo tam można skręcić kostkę albo nogę, bo może się zawalić ziemia”. Obserwacje te nieodmiennie łączą się z postaciami reprezentującymi personel muzealny. Są to zazwyczaj „panie” $i$ „panowie”, zatem osoby dziecku obce, ale także przewodnicy, co świadczy o wiedzy wyniesionej z praktyki zwiedzania muzeum. Charakterystyczna jest opinia o pracy muzealników. Dziecko zapytane o to, po co jest muzeum, odpowiedziało: „żeby ciężko nie pracować”. Nie można wyzbyć się wrażenia, że opinia ta związana jest z obserwacją pilnujących ekspozycji osób , które zwykle stoją lub siedzą, nie wykonując czynności kojarzących się dziecku z pracą. Inne z dzieci doceniło zaś pracę przewodnika, którego określiło mianem „kierownika” - zatem osoby ważnej i mądrej: „Tam [w muzeum - J.S.] się robi takie rzeczy, że na przykład jakiś tam pomnik stoi i można go podziwiać, i pytać się kierownika, co to jest za człowiek albo pomnik".

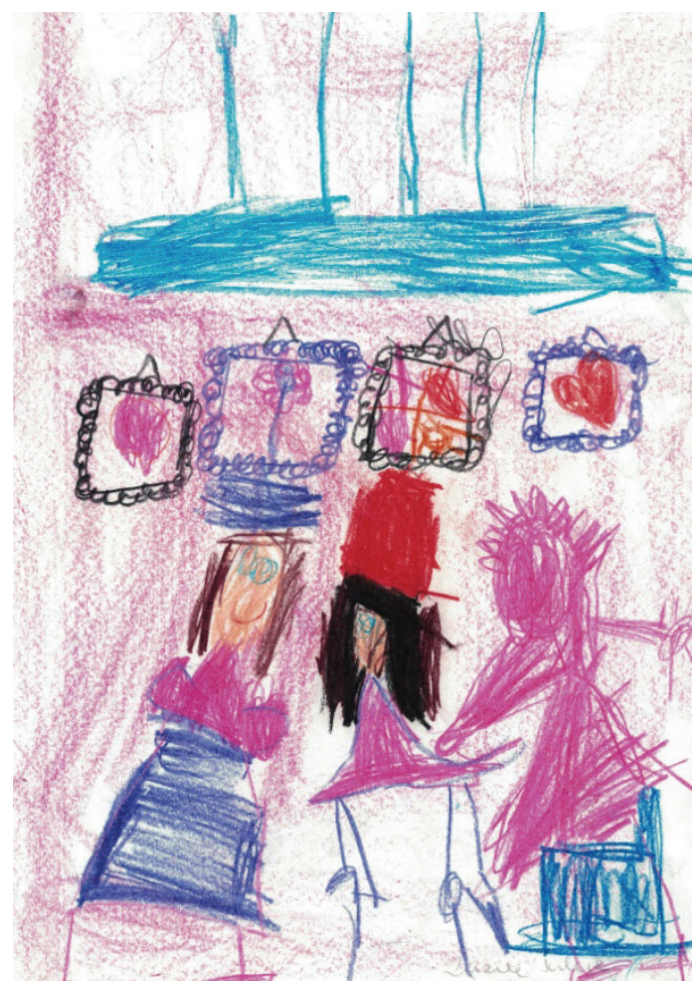

Rys.10. Zuzanna, lat 6, Muzeum.

Wystawa odbyła się w Muzeum Śląska Cieszyńskiego w ramach 11. Nocy Muzeów w 2018 roku (25 maja) 
Dzieci potrafią także krytycznie odnieść się do pewnych zachowań, szczególnie tych, które zakłócają proces zwiedzania. Twierdzą zatem, że nie lubią ludzi „na telefonach (...). Po co mają w ogóle przyjść do muzeum, jak nie oglądają i się nie interesują. Ale mogą być na telefonach, jak robią ważne rzeczy, albo kamerują to, robią zdjęcia”. Korzystanie z telefonów w muzeum dzieci tłumaczą koniecznością pozostawania w permanentnym kontakcie $\mathrm{z}$ miejscem pracy: „poszli do muzeum, a mieli iść do pracy i muszą teraz pisać ze swoją pracą". Taka wizyta w ich opinii jest bezzasadna, ponieważ osoba rozmawiająca przez telefon nie może skupić się na zwiedzaniu, a nadto rozprasza dzieci. To obserwacje, które podkreślają tylko, jakiego typu bodźce działają na zwiedzające dzieci i które z nich mogą stymulować lub hamować ich zainteresowanie.

Dokonując pierwszego uogólnienia wyników badań, nie sposób oprzeć się wrażeniu, ze dzieci intuicyjnie prawie odtwarzają wszystkie funkcje przypisywane muzeum od początków jego powstania. Ich wyobrażenia wręcz współbrzmią z definicją autorstwa Georges’a Henriego Riviere’a, który pisze:

Muzeum jest instytucją trwałą, nie obliczoną na zysk, pozostającą w służbie społeczeństwa i jego rozwoju, otwartą dla publiczności, mającą za zadanie gromadzenie, konserwowanie, badanie, rozpowszechnianie i wystawianie materialnych świadectw dotyczących człowieka i jego otoczenia, a to dla studiowania, edukacji i przyjemności [Folga-Januszewska 2008: 200].

Ostatnie zdanie definicji jest bardzo ważne. Dzieci pytane o to, czemu muzeum ma służyć, odpowiadały: „żeby ludzie byli ciekawi”. W tym jednym zdaniu kryje się cały społeczny potencjał tej instytucji, której funkcje publiczne streszczają się w zadaniach naukowych, edukacyjnych i przyjemnościowych.

Po wstępnej zaledwie prezentacji wyników badań warto postawić pytanie: Czy zajmowanie się dziecięcymi wyobrażeniami na temat muzeum ma znaczenie dla kształtowania ich (muzeów) edukacyjnej, a nawet szerzej - społecznej praktyki? Badania Marii Kielar, choć dotyczą innych sfer zainteresowań, rzucają światło i na to zagadnienie. Badaczka wykazała, że największy potencjał rozwojowy w wieku przedszkolnym kryje sfera wyobrażeń. Właściwości dziecięcych wyobrażeń współkształtują w jej opinii całe systemy pojęć, rozumowanie a także wywierają wpływ na rozwój społeczny dziecka w kolejnych etapach życia [Kielar 1978]. A skoro materiał wyobrażeniowy stanowi tak ważny składnik fundamentalnych procesów rozwojowych, nie można go lekceważyć, zwłaszcza wówczas, gdy muzeum chce świadomie realizować zadania o charakterze kształcącym i wychowawczym. 


\section{Zakoniczenie}

W badaniach działalności instytucji kultury, w tym muzeów, merkantylne ${ }^{9}$ podejście do ich oferty jest niewystarczające. Kształtowanie więzi z instytucją kultury jest zjawiskiem dużo poważniejszym, gdy rozpatrujemy je z perspektywy realizacji jej misji edukacyjnej. Jeśli bowiem instytucje mają realizować zadania edukacyjne, co znaczy kształcić i wychowywać (to zwykle zapoznawana przez organizatorów programów edukacyjnych w instytucjach kultury część pojęcia), to muszą wiedzieć, kto do nich przychodzi, zatem co najmniej, z jakimi doświadczeniami, wiedzą i przekonaniami trafiają do nich potencjalni uczestnicy oferty. W tym znaczeniu, od oceny stosunku publiczności do instytucji powinny rozpoczynać się każda analiza i projektowanie działań skierowanych do określonej grupy odbiorców. Warto i z tego względu przyjrzeć się obrazowi muzeum, który cechuje dzieci najmłodsze. Zainteresowanie ich opiniami jest istotne ze względu na fakt, że coraz częściej i szerzej muzea światowe otwierają się na najmłodszą publiczność. Projektując działania dla najmłodszych odwiedzających, warto jednak zdawać sobie sprawę, że jest to grupa odbiorców odznaczająca się szczególną wrażliwością, jako że znajduje się na etapie kształtowania się podstaw dojrzałej osobowości. Zatem praca ta wymaga szczególnego skupienia i rzetelnej wiedzy. Stąd zrodził się projekt realizacji badań skupionych na najmłodszej populacji odwiedzających muzea. Ich wczesne, pozytywne wyobrażenia na temat instytucji powinny być bowiem pielęgnowane, wzbogacane w taki sposób, aby przekuły się ostatecznie w pozytywny wizerunek muzeum jako miejsca (w pełnym tego pojęcia znaczeniu), wartościowego i znaczącego jednostkowo oraz społecznie. Efekt ten jest szczególnie istotny wobec postulowanego przez środowiska muzealne (w tym propagatorów idei nowej muzeologii) angażowania się muzeów w życie współczesnych wspólnot, pełniąc wobec nich wartościotwórczą rolę. Postulat ten mocno wybrzmiał na I Kongresie Muzealników Polskich w 2015 roku:

Prawie wszystko, co jeszcze do niedawna mówiono i pisano o muzeach, co traktowano jako niemalże oczywistość, jako zespół twierdzeń na krawędzi niesporności, dzisiaj staje się przedmiotem dyskusji. Dyskusja zaś jest dość osobliwa. Obok argumentów odwołujących się do dorobku muzeologii, teorii organizacji, psychologii społecznej i nauk metrycznych przewija się przez nią silny wątek aksjologiczny, niepozbawiony w dodatku akcentów emocjonalnych. Rzecz idzie o rolę muzeów w społeczeństwie. Nie tylko o to, jak mają służyć społeczeństwu chroniąc jego dziedzictwo, ale o to, jak powinny wpływać na poziom intelektualny i brać

${ }^{9}$ Celnie podsumowała tę orientację Dorota Folga-Januszweska, pisząc, że „umilkła dyskusja nad celowością zwiększenia przychodów muzeów oraz wzrostu frekwencji, gdyż stało się jasne, że instytucje te są nie tylko z nazwy, ale ze swej istoty non profit, a wypełnianie misji edukacyjnej, artystycznej i naukowej musi dokonywać się z pomocą innych źródeł finansowania [niż stałe czerpanie zysków z powiększającej się publiczności - J.S.]” [Folga-Januszewska 2009: 35]. 
udział w kształtowaniu jego wartości etycznych. Inaczej mówiąc, rzecz idzie o fundamentalne wartości naszego społeczeństwa, którego cząstką jest społeczność muzealników. Takimi wartościami są poszanowanie zasad demokratycznego państwa prawnego, wolności oraz praw człowieka i obywatela, ochrona dziedzictwa narodowego i świata, a także przyjazne uczestnictwo we wspólnocie międzynarodowej. Misją muzeum jest właśnie ochroną tych wartości [Waltoś 2015: 25].

Wyobrażenia o instytucji, a także późniejszy jej obraz, wpływają niewątpliwie na inne sfery jego funkcjonowania. Potrzeba działań skoncentrowanych na kształtowaniu wizerunku jest coraz częściej podkreślana przez gremia zajmujące się zarządzaniem. Uznaje się, że właściwy, tzn. pozytywny wizerunek firmy w jej społecznym otoczeniu sprzyja zdobywaniu przewagi konkurencyjnej i wzmaga efektywność na wszystkich polach jej działalności [Altkorn 2002]. Wizerunek, choć potocznie łączony z zewnętrznością, dotyczy jednak wielu aspektów działalności instytucji. W definicjach określany jako złożona intelektualna lub zmysłowa interpretacja, sposób postrzegania kogoś lub czegoś, wytwór umysłu wynikający z dedukcji opartej na dostępnych przesłankach, zarówno realnych, jak i wyobrażonych, uwarunkowany wrażeniami, przekonaniami, ideami i emocjami, jest rodzajem opinii, jaką otoczenie buduje na temat instytucji [Davis 2007]. Stanowi pewnego rodzaju obraz wykreowany w umysłach ludzi, który wynika z oceny jej działalności, doświadczeń z kontaktów z nią, wyobrażeń, poglądów i oczekiwań wobec niej wysuwanych [Wójcik 2009] i funkcjonuje jako symbol pewnych wartości nakładanych na instytucję. Dbałość o pozytywny wizerunek firmy, również z perspektywy zarządzania nią, niesie więc bardzo określone korzyści, bo wpływa na kształtowanie się relacji pomiędzy instytucją a jej otoczeniem, co oznacza, że niweluje obojętność względem niej. Po wtóre, zjednuje publiczność dla jej produktów i wzmacnia lojalność wobec jej klasycznych form funkcjonowania, a także ułatwia wprowadzanie na rynek nowości. Wszystkie te elementy przekładają się na zysk przedsiębiorstwa, a co równie ważne, wzmacniają satysfakcję jej pracowników, która wspiera ich lojalność względem firmy [Pawlak-Kołodziejska 2011].

Bez względu na to, z jakiej perspektywy przyglądamy się wizerunkowi firmy, pierwszorzędne znaczenie ma człowiek oceniający. Warto poznać jego wyobrażenie na temat instytucji. Od tego obrazu, który kształtuje się już we wczesnym dzieciństwie, zależy także właściwe funkcjonowanie i przetrwanie owej instytucji. 


\section{Biblioggrafia}

Altkorn J. (2002), Kształtowanie rynkowego wizerunku firm, Kraków: Wydawnictwo Akademii Ekonomicznej w Krakowie.

Bourdieu P., Darbel A. (1991), The love of art: European art museums and their public, Cambridge: Polity Press.

Bruner J. (1978), Poza dostarczone informacje, tłum. B. Mroziak, Warszawa: PWN.

Debray R. (2010), Wprowadzeniu do mediologii, tłum. A. Kapciak, Warszawa: Oficyna Naukowa. Doering Z.D., Bickford A., Pekarik A.J. (1997), Visitors to the Smithsonian Institution: A summary of studies. Report 97-3, „Institutional Studies”, Washington: Smithsonian Institution.

Davis A. (2007), Public relations, tłum. G. Dąbkowski, Warszawa: PWE.

Folga-Januszewska D. (2008), Muzeum: definicje i pojęcia. Czym jest muzeum dzisiaj?, „Muzealnictwo", nr 49, s. 200-203.

Folga-Januszewska D. (2009), Raport o muzeach 1989-2008, „Muzealnictwo”, nr 50, s. 18-46.

Gloton R., Clero C. (1985), Twórcza aktywność dziecka, tłum. I. Wojnar, Warszawa: WSiP.

Higgins H.H. (1884), Museum of Natural History, Liverpool: Transactions of the Literary and Philosophical Society of Liverpool.

Hornowska E., Paluchowski W. (1987), Rysunek postaci ludzkiej Goodenough Harrisa, Poznań: Wydawnictwo Naukowe Uniwersytetu im. Adama Mickiewicza.

Hurlock E. (1985), Rozwój dziecka, tłum. M. Tyszkowa, t. 1-2, Warszawa: PWN.

Kielar M. (1987), Wyobrażenia i sposoby stymulowania ich rozwoju w wieku przedszkolnym, Kraków: Wydawnictwo Naukowe Akademii Pedagogicznej w Krakowie.

Kostrubiec B., Mirucka B. (2007), Rysunek projekcyjnych w badaniach relacji społecznych. Lublin: Towarzystwo Naukowe KUL.

Lisek-Michalska J., Daniłowicz P. (red.) (2004), Fokus - zogniskowany wywiad grupowy, studia nad metoda, Łódź: Wydawnictwo Uniwersytetu Łódzkiego.

Maison D. (2001), Zogniskowane wywiady grupowe. Jakościowa metoda badań marketingowych, Warszawa: Wydawnictwo Naukowe PWN.

Mikułowski-Pomorski J. (1973), Badania nad publicznościa muzealną w Polsce, „Muzealnictwo", nr 21, s. 74-83.

Muzea w Polsce. Raporty na podstawie danych z projektu Statystyka muzeów (2013-2015), Warszawa: Narodowy Instytut Muzealnictwa i Ochrony Zbiorów, 2016.

Nęcka E., Orzechowski J., Szymura B. (2006), Psychologia poznawcza. Warszawa: Academica Wydawnictwo SWPS - Wydawnictwo Naukowe PWN.

Paivio A. (1991), Dual Coding Theory: Retrospect and current status, „Canadian Journal of Psychology", Vol. 45, Issue 3, s. 255-287.

Pawlak-Kołodziejska K. (2011), Kształtowanie wizerunku przedsiębiorstwa za pomoca działań z zakresu public relation, „Zeszyty Naukowe Ostrołęckiego Towarzystwa Naukowego”, nr 25.

Piaget J., Inhelder B. (1967), Obrazy umystowe, [w:] P. Olderon, J. Piaget, B. Inhelder, P. Greco, Inteligencja, Warszawa: PWN. 
Przetacznik-Gierowska M. (1993), Świat dziecka: aktywność, poznanie, środowisko, Kraków: Wydawnictwo Uniwerystetu Jagiellońskiego.

Przetacznikowa M. (1975), Wiek przedszkolny, [w:] M. Żebrowska (red.), Psychologia rozwojowa dzieci i młodzieży, Warszawa: PWN, s. 416-519.

Przetacznikowa M. (2000), Psychologia rozwoju człowieka, Warszawa: PWN.

Przetacznikowa M., Makiełło-Jarża M. (1974), Psychologia rozwojowa, Warszawa: WSiP.

Rembowski J. (1986), Metoda projekcyjna w psychologii dzieci i młodzieży. Zarys technik badawczych, Warszawa: PWN.

Skutnik J. (2018), Edukacja dla rodzin w instytucji kultury - przypadek muzeum, [w:] Rodziny/2015, Seniorki i seniorzy/2016 w instytucji kultury, Poznań: Centrum Turystyki Kulturowej TRAKT, s. 39-53.

Soeven C.G. (1993), États-Unis d'Amérique: Une science en formation, „Museum International”, No. 178, Vol. 45, Issue 2, s. 6-12.

Statystyka muzeów. Muzea w 2016 roku, Warszawa: Narodowy Instytut Muzealnictwa i Ochrony Zbiorów, Warszawa 2017.

Szuman S. (1990), O sztuce i wychowaniu estetycznym, Warszawa: WSiP.

Szuman S. (2008), Wybór pism estetycznych, oprac. M. Kielar-Turska, Kraków: Universitas.

Waltoś S. (2015), Misja, etyka, wartości. Pytania o wartościotwórczą rolę muzeów, I Kongres Muzealników Polskich, Warszawa: Narodowe Centrum Kultury.

Wójcik K. (2009), Public relations. Wiarygodny dialog z otoczeniem, Warszawa: Oficyna Wolters Kluwer Business.

Ziembiński J. (1990), Stan badań socjologicznych nad społeczną percepcją zbiorów muzealnych $w$ Polsce, „Materiały Muzeum Wnętrz Zabytkowych w Pszczynie”, t. 6, Pszczyna, s. 194-205. 